\title{
The oldest stage of the Outer Carpathian evolution in the light of Oxfordian-Kimmeridgian exotic clast studies (southern Poland)
}

\author{
Justyna Kowal-Kasprzyk ${ }^{1}\left[\right.$ D $\cdot$ Marcin Krajewski ${ }^{1} \cdot$ Przemysław Gedl $^{2}$
}

Received: 21 August 2019 / Accepted: 11 February 2020 / Published online: 24 February 2020

(c) The Author(s) 2020

\begin{abstract}
In the Late Jurassic, the rifting process led to the disintegration of the southern margin of the North European Platform and to the opening of the Outer Carpathian flysch basin sedimentary system. The initial sediments accumulated in the northern part of the basin are related to both the destruction and resedimentation of older platform deposits. Since the sedimentary succession of this pre-flysch phase was consumed by the Miocene subduction, its only traces are represented, nowadays, by clasts preserved as exotics in the succeeding flysch deposits. Our analysis of foraminifers as well as calcareous and organic dinoflagellate cysts found in these exotics confirms the Oxfordian-early Kimmeridgian timing of the platform phase that preceded the opening of the flysch basin. The exotics are represented by three main facies types: sponge-microbial limestones, oncoid-intraclastic-Crescentiella limestones and fine-grained, biodetrital limestones with Saccocoma. These deposits are related to mid-ramp to outer-ramp settings. The land influence was rather weak, and these sedimentary settings were dominated by pelagic/hemipelagic accumulation. The studied facies are similar to facies types widely distributed over the northern shelf area of the Western Tethys (e.g., extra-Carpathian southern Poland, Carpathian Foredeep basement, southern Germany). In turn, coeval strata known from the part of the Magura Basin and of the Penninic-Pieninic Ocean, which were situated in more southern part of the Tethys, yielded different microfacies reflecting significant differences between the sedimentary settings of the study area and its southern extensions.
\end{abstract}

Keywords Upper Jurassic $\cdot$ Facies/microfacies $\cdot$ Microfossils $\cdot$ Palynology $\cdot$ Paleogeography $\cdot$ Outer Carpathians

\section{Introduction}

The uppermost Jurassic deposits, although fragmentarily preserved due to a high tectonic engagement, are well known from the Outer Carpathian outcrops. This contrasts both the underlying platform strata and the deposits from the margins and intrabasinal ridges, which were either eroded or consumed during the Miocene subduction (Książkiewicz

Electronic supplementary material The online version of this article (https://doi.org/10.1007/s10347-020-0595-y) contains supplementary material, which is available to authorized users.

Justyna Kowal-Kasprzyk

kowalj@agh.edu.pl

1 Faculty of Geology, Geophysics and Environmental Protection, University of Science and Technology (AGH), Al. Mickiewicza 30, 30-059 Kraków, Poland

2 Institute of Geological Sciences, Polish Academy of Sciences, Research Centre in Kraków, Senacka 1, 31-002 Kraków, Poland 1956b, 1977). The only remnants of the latter are crystalline and sedimentary clasts-i.e., the "exotics" (Hohenegger 1861), which are also the only evidence of the sedimentation mode that preceded the opening of the Carpathian flysch basins and which later proceeded along their margins. Studies on exotics allow to reconstruct the paleogeography as well as the geological and the sedimentological history of the destroyed parts of the Carpathian basins and their surroundings (e.g., Nowak 1927; Książkiewicz 1931, 1965).

The exotics occur in various lithostratigraphic units of the Outer Carpathians. They show various dimensions: from large blocks, several tens of meters across, which form isolated klippes, e.g., in the Štramberk (Czech Republic) and in the Andrychów (Poland) areas, to relatively common, pebble- and cobble-sized clasts. The most common and the best recognized exotics in the Polish Outer Carpathians are the remnants of Tithonian-lowermost Cretaceous, shallowwater carbonate platform deposits (the so-called Stramberktype limestones; for an overview, see Kołodziej 2015). Other examples are Tithonian pelagic limestones as well as 
Devonian, Carboniferous, Cretaceous, and Paleogene carbonate rocks (e.g., Nowak 1927; Książkiewicz 1956b; Oszczypko 1975; Burtan et al. 1984; Miš́́k et al. 1991; Rajchel and Myszkowska 1998; Oszczypko et al. 2006; Olszewska et al. 2011).

The clasts of Oxfordian-Kimmeridgian calcareous rocks, which were deposited just prior to and during the opening of the proto-Silesian Basin, are also known from the Outer Carpathians. They were observed by, e.g., Nowak (1927), Książkiewicz (1931), Burtan et al. (1984), and Matyszkiewicz and Słomka (2004), but their more detailed studies are limited mainly to the Bachowice exotic blocks and the Andrychów Klippes (e.g., Książkiewicz 1956a; Nowak 1976; Olszewska and Wieczorek 2001; Olszewska et al. 2011). As this age range is crucial to the reconstruction of the paleogeography and sedimentary conditions of the early stages of the Carpathian basin development, we investigated Oxfordian-Kimmeridgian exotic carbonate clasts from the Polish Outer Carpathians. Following a preliminary description of the Oxfordian-Kimmeridgian clasts from two localities in the Beskid Mały Mts. included in Strzeboński et al. (2017), we present here the detailed micropaleontological, palynological and microfacies study of exotics coming from these two localities as well as 10 additional sites in the western part of both the Silesian and Subsilesian units of the Polish Outer Carpathians. Our results are compared with the epicontinental deposits from the northern margin of the Carpathian basins known from both outcrops and boreholes. The Oxfordian-Kimmeridgian paleogeographical background is also presented, in accordance with the contemporary interpretations.

\section{Geology}

\section{Geological background}

In the Late Jurassic, an important phase of plate reorganization took place in the Tethyan-Alpine domain. A rifting process disintegrated the southern margin of the North European Platform composed of the Precambrian crystalline basement and the Paleozoic-Mesozoic sedimentary cover (e.g., Birkenmajer 1988; Olszewska and Wieczorek 2001; Golonka 2004; Golonka et al. 2000, 2006; Aubrecht and Szulc 2006). It resulted in the opening of new basins in the latest Jurassic-Miocene that formed the northernmost, peripheral part of the western Tethyan Ocean. In our study area, the rifting-related break-up of the carbonate platform led to the formation of the NW-SE-elongated, Outer Carpathian Severin-Moldavidic Basin (Balintoni 1998), also called the proto-Silesian Basin (e.g., Golonka et al. 2008a). The new basins were separated by ridges built of the relics of the North European Platform, e.g., the Baška-Inwałd
Ridge and the Silesian Ridge (e.g., Książkiewicz 1965; Matyszkiewicz and Słomka 2004; Golonka et al. 2008a). The narrow Bachowice Basin is supposed to be situated north of the proto-Silesian Basin and the Baška-Inwałd Ridge (Książkiewicz 1956a). The proto-Silesian basin evolved subsequently into the Outer (Flysch) Carpathian sub-basin system, which included the Silesian, the Subsilesian, and the Skole basins, bordered on the south by the Silesian Ridge that separated them from the largest Outer Carpathian Magura Basin.

The timing of this carbonate platform break-up can be deduced from dating of the oldest deposits accumulated in the flysch basins. These are dark marly shales and, subordinately, pelitic and detrital limestones of the Vendryně Formation (after Eliáš et al. 2003), formerly known as the Lower Cieszyn Shale (after Hohenegger 1861). Their deposition began presumably in the latest Kimmeridgian/earliest Tithonian (Olszewska et al. 2008) but they are mostly of Tithonian age (Skupien and Smaržová 2011; Skupien and Doupovcová 2019; Salamon et al. 2019), although the former Czech literature did not exclude the older (even Oxfordian) age of these beds based on ammonites (Vašíček 1972). They are overlain by uppermost Tithonian-lowermost Cretaceous calciturbiditic deposits (Cieszyn Limestone or Cieszyn Limestone Formation), and the Upper Cieszyn Shale (Cisownica Shale Member of the Hradiště Formation after Golonka et al. 2008b). In the Early Cretaceous, when erosion reached the crystalline basement, the siliciclastic flysch sedimentation has begun.

\section{Geological setting}

The study area is located in the western sector of the Outer (Flysch) Carpathians, southern Poland, between the Soła and the Dunajec rivers, in the Beskidian Foothills and the Beskidy Mts. Range. Tectonically, the study area represents the western part of the Silesian and Subsilesian nappes, bordered to the south by the Magura Nappe-the largest nappe of the Outer Carpathians (Fig. 1). To the north, both nappes are thrusted over the autochthonous and the folded Miocene strata (Stebnik and Zgłobice units) of the Carpathian Foredeep. The uppermost Jurassic-Miocene succession of the Silesian Unit is built mainly of flysch deposits (Fig. 2). The Subsilesian Unit, in turn, represents the Lower Cretaceous-Miocene sequence deposited under shallower conditions than the Silesian Unit, possibly on the slope of the Subsilesian Ridge (e.g., Ślączka et al. 2006), which developed at the end of the Early Cretaceous (e.g., Książkiewicz 1965; Golonka et al. 2000). 


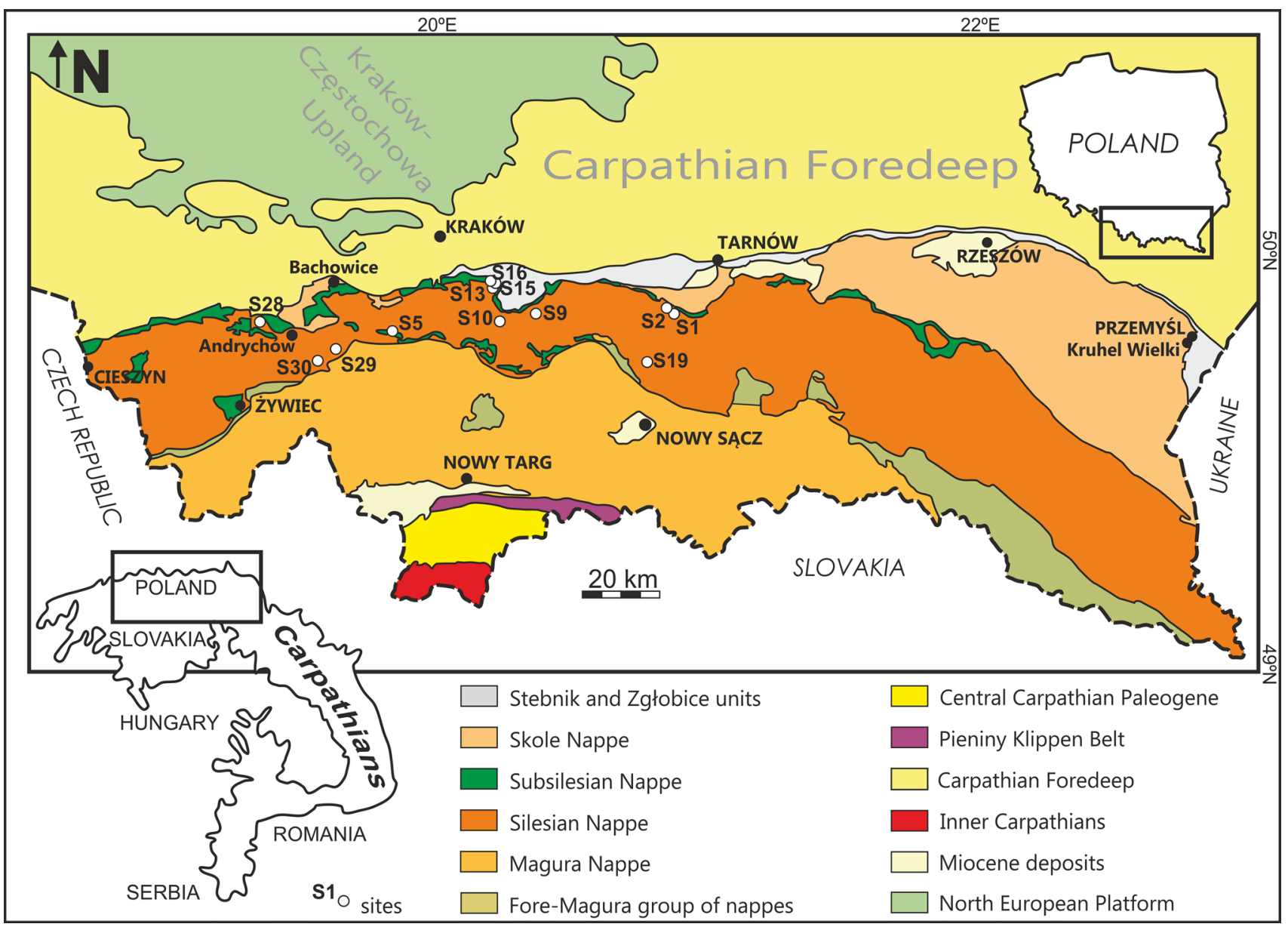

Fig. 1 Position of the study area against the tectonic map of the Polish Carpathians and their foreland (map after: Żytko et al. 1989; Cieszkowski et al. 2009). Sites: S1-Roztoka, S2-Milówka, S5-
Lanckorona, S9-Kobylec, S10—Krzyworzeka, S13-Sułów, S15Trąbki, S16-Biskupice, S19-Gródek nad Dunajcem, S28-Mały Czaniec, S29-Mucharz, S30—Targoszów

\section{Materials and methods}

The studied exotics come from Lower Cretaceous to Eocene strata (Fig. 2, Table 1) exposed at 12 sites (Fig. 1) distributed along stream and lake banks (Fig. 3). In these outcrops, the calcareous exotics are represented by Tithonian-Berriasian limestones (mainly Štramberk-type limestones), Oxfordian-Kimmeridgian limestones, and, only occasionally, by Paleogene and Paleozoic carbonates (Kowal-Kasprzyk 2016). The Oxfordian-Kimmeridgian clasts are less common than the Tithonian-Berriasian ones; the former were absent in 19 of 31 sites studied by Kowal-Kasprzyk (2016). The exceptions are two localities in the Beskidy Range (sites: Mucharz-S29, and Targoszów-S30) where the Oxfordian-Kimmeridgian calcareous clasts are common; whereas, the Štramberk-type exotics are relatively rare (see also Strzeboński et al. 2017).

The samples were analyzed macro- and microscopically. Microfossils and microfacies were studied in standard thin sections under the polarizing microscope equipped with digital camera. Totally, 30 samples of all the analyzed pebbles and cobbles (a few up to $25 \mathrm{~cm}$ in size) were identified as the Oxfordian-Kimmeridgian rocks and were used in our study (Table 2; see also Electronic Supplementary Material) (samples from sites S29 and S30 were also used by Strzeboński et al. 2017). Additionally, the 18 exotic clasts were selected for palynological studies (Table 2). They were subjected to relevant sample preparation including the removal of carbonates (with $\mathrm{HCl}$ ) and silicates (with $\mathrm{HF}$ ), sieving on $15-\mu \mathrm{m}$ mesh nylon sieve, and heavy liquid separation. No oxidation was applied. Palynological slides (with glycerine jelly as a mounting medium) were examined under the Axiolab Zeiss microscope ( $100 \times$ oil lens); photomicrographs were taken using the Sony DSC-75 camera. The biostratigraphy was based on known ranges of foraminifera as well as calcareous and organic-walled dinoflagellate cysts. The thin sections are stored in the University of Sciences and Technology (Kraków), and the palynological residues and 
Fig. 2 Generalized lithostratigrapic column of the Silesian Unit (a) (after Cieszkowski et al. 2009, modified) and the lower part of the generalized lithostratigraphic column of the Subsilesian Unit (b) (after e.g., Ślączka et al. 2006, modified) with marked position of the studied exotics

slides are stored in the collection of the Institute of Geological Sciences, Polish Academy of Sciences (Kraków).

\section{Results}

\section{Facies and microfacies analysis}

The studied exotics represent three facies types (FT 1-3): (i) light-beige, porous, sponge-microbial limestones (FT 1), (ii) beige, nonporous, oncoid-intraclastic-Crescentiella limestones (FT 2) and (iii) dark-gray, fine-grained, biodetrital limestones with Saccocoma (FT 3) (Figs. 4, 5; Table 3; see also Electronic Supplementary Material).

\section{FT 1: sponge-microbial limestones}

The first facies type-sponge-microbial limestones (FT 1)— comprises limestones with numerous dish-shaped sponges and/or fine-grained bioclastic limestones (Fig. 4a-c). The FT 1 facies includes two main types of microfacies: (i) sponge-microbial framestones-floatstones (Fig. 4a, b) and (ii) fine-grained bioclastic wackestones-packstones (Fig. 4c). The first microfacies type embraces calcified siliceous sponges (Lithistida and Hexactinellida) onto which clotted thrombolites (Fig. 4a) or, less frequently, micritic stromatolites grew (cf. Schmid 1996; Riding 2000). Growth cavities as well as borings geopetally filled with partly silicified internal sediments are common. Tuberoids of diameters up to $1.7 \mathrm{~cm}$ are abundant as well as microencrusting organisms, usually bryozoans, foraminifers (Nubecularia, Bullopora; see: Fig. 6a), serpulids and agglutinating annelids Terebella lapilloides (Fig. 6b). Some samples are enriched with individual forms of Crescentiella morronensis (incertae sedis; e.g., Senowbari-Daryan et al. 2008; Pleş et al. 2017; Krajewski and Schlagintweit 2018) (Fig. 6c).

The second microfacies type comprises fine-grained bioclastic wackestones or packstones composed mostly of peloids, brachiopods, spicules, foraminifers, calcareous dinocysts (Fig. 7), crinoids, recrystallized radiolarians, echinoids, as well as bivalves, gastropods, ophiuroid ossicles, zoospores Globochaete alpina, ostracod carapaces, fragments of ammonites as well as numerous tuberoids and bioclasts (Fig. 4c). Foraminifers are represented by calcareous (Cornuspira, Spirillina, Lenticulina, Protopeneroplis, Rumanolina, Epistominidae, nodosarids, Ophthalmidium and less common other miliolids; see: Fig. $6 \mathrm{~d}-\mathrm{j}$ ) and agglutinated

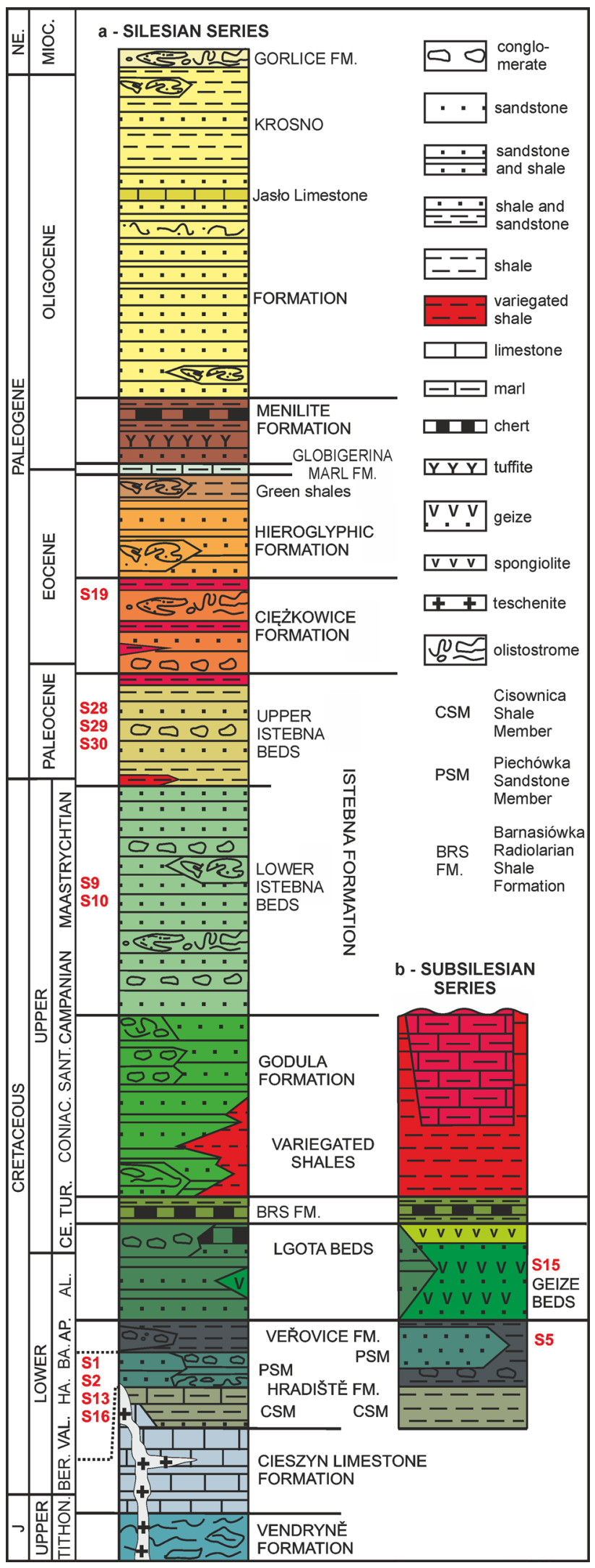


Table 1 Localities of studied outcrops (lithostratigraphy after Bieda et al. 1963, modified)

\begin{tabular}{llll}
\hline Name and symbol of the locality & Tectonic unit & Lithostratigraphy & Coordinates \\
\hline Roztoka (S1) & Silesian & Hradiště Formation-Piechówka Sandstone Member & $49^{\circ} 52^{\prime} 6.14^{\prime \prime} \mathrm{N} ; 20^{\circ} 48^{\prime} 4.18^{\prime \prime} \mathrm{E}$ \\
Milówka (S2) & Silesian & (Hauterivian-Aptian) & $49^{\circ} 54^{\prime} 54.1^{\prime \prime} \mathrm{N} ; 20^{\circ} 46^{\prime} 47.2^{\prime \prime} \mathrm{E}$ \\
Lanckorona (S5) & Subsilesian & & $49^{\circ} 50^{\prime} 26.3^{\prime \prime} \mathrm{N} ; 19^{\circ} 44^{\prime} 23.5^{\prime \prime} \mathrm{E}$ \\
Sułów (S13) & Silesian & $4^{\circ} 57^{\prime} 10.8^{\prime \prime} \mathrm{N} ; 20^{\circ} 06^{\prime} 42.6^{\prime \prime} \mathrm{E}$ \\
Biskupice (S16) & Silesian & $4^{\circ} 57^{\prime} 30.2^{\prime \prime} \mathrm{N} ; 20^{\circ} 07^{\prime} 01.5^{\prime \prime} \mathrm{E}$ \\
Trąbki (S15) & Subsilesian & Geize Beds (Albian-Cenomanian) & $49^{\circ} 57^{\prime} 33.2^{\prime \prime} \mathrm{N} ; 20^{\circ} 08^{\prime} 03.2^{\prime \prime} \mathrm{E}$ \\
Kobylec (S9) & Silesian & Istebna Formation-Lower Istebna Beds (Campanian-Maas- $49^{\circ} 53^{\prime} 13.8^{\prime \prime} \mathrm{N} ; 20^{\circ} 16^{\prime} 57.0^{\prime \prime} \mathrm{E}$ \\
Krzyworzeka (S10) & Silesian & trichtian) & $49^{\circ} 52^{\prime} 06.4^{\prime \prime} \mathrm{N} ; 20^{\circ} 08^{\prime} 37.7^{\prime \prime} \mathrm{E}$ \\
Mały Czaniec (S28) & Silesian & Istebna Formation-Upper Istebna Beds (Paleocene) & $49^{\circ} 51^{\prime} 38.8^{\prime \prime} \mathrm{N} ; 19^{\circ} 15^{\prime} 46.7^{\prime \prime} \mathrm{E}$ \\
Mucharz (S29) & Silesian & & $49^{\circ} 49^{\prime} 15.9^{\prime \prime} \mathrm{N} ; 19^{\circ} 32^{\prime} 33.1^{\prime \prime} \mathrm{E}$ \\
Targoszów (S30) & Silesian & & $49^{\circ} 45^{\prime} 17.2^{\prime \prime} \mathrm{N} ; 19^{\circ} 27^{\prime} 35.3^{\prime \prime} \mathrm{E}$ \\
Gródek nad Dunajcem (S19) & Silesian & Ciężkowice Formation (Upper Paleocene-Eocene) & $49^{\circ} 43^{\prime} 56.8^{\prime \prime} \mathrm{N} ; 20^{\circ} 43^{\prime} 17.2^{\prime \prime} \mathrm{E}$ \\
\hline
\end{tabular}
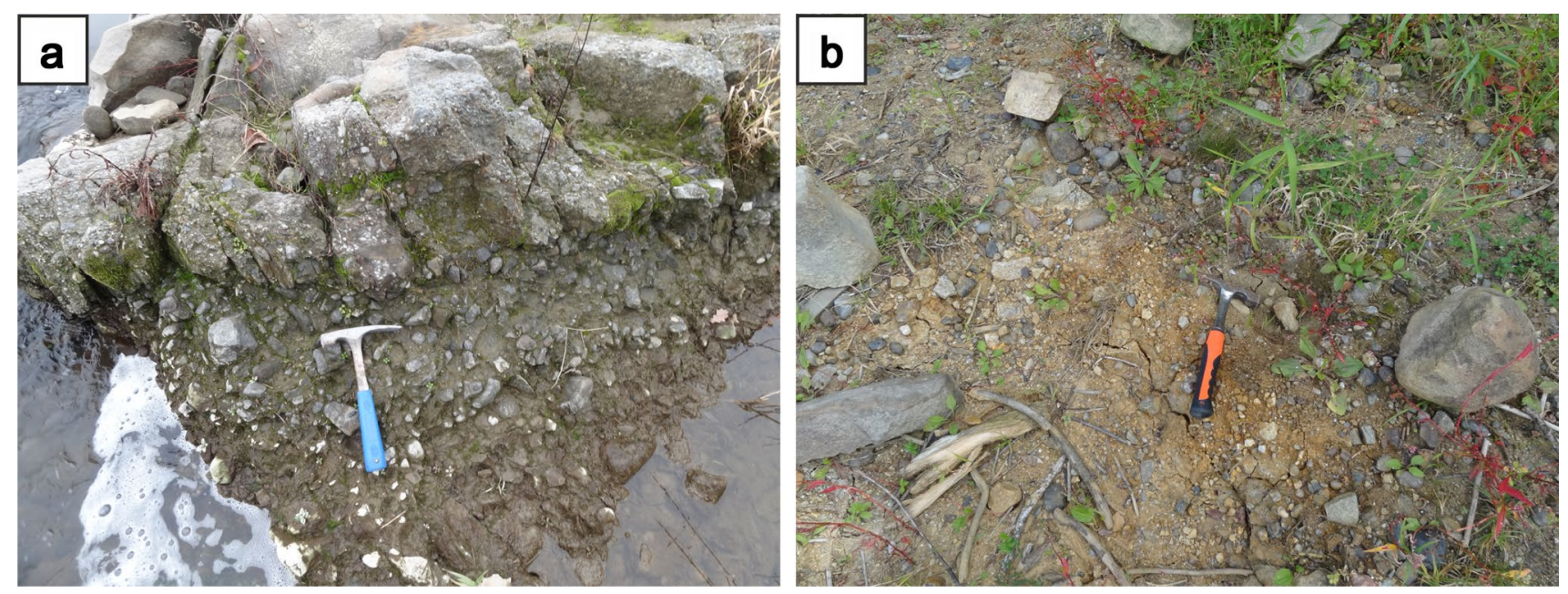

Fig. 3 Examples of outcrops with studied exotics (photo: J. Kowal-Kasprzyk). a Mucharz (S29), conglomerate with exotics, Istebna Formation, Upper Istebna Beds. b Gródek nad Dunajcem (S19), weathered surface of conglomerate with exotics, Ciężkowice Formation

forms (such as Protomarssonella, Eomarssonella, Reophax and Ammobaculites; see: Fig. 6k, 1), and rare planktonic forms ("globuligerinids"; see: Fig. 6m, n) encountered only in some samples. Sometimes, thin leiolites (sensu Schmid 1996) can be observed. Silicification is frequent in bioclastic wackestones-packstones as impregnations of microcrystalline quartz (cf. Matyszkiewicz et al. 2015). In most cases, the matrix is silicified; whereas the grains remain unaltered. In the framestones, the silicification is poor.

\section{FT 2: oncoid-intraclast-Crescentiella limestones}

The oncoid-intraclast-Crescentiella limestones (FT 2) represent a facies dominated by detrital limestones composed mainly of various coated grains, intraclasts, bioclasts and numerous Crescentiella specimens. The microfacies types include: (i) oncoid-intraclast floatstones-wackestones and (ii) Crescentiella-peloidal wackestones, also bindstones (less commonly) (Fig. 4d-f). The first microfacies consists of abundant, small, oval oncoids, usually up to $1 \mathrm{~mm}$ in diameter (type I, rarely type II; e.g., Flügel 2004; Vedrine et al. 2007), cortoids and irregular intraclasts, up to $3 \mathrm{~mm}$ across (Fig. 4f). The surfaces of subangular intraclasts are commonly coated by microbial envelopes. Frequent are aggregate grains with cores built of peloids, micritic ooids and bioclasts (Fig. 4d). Among bioclasts small bivalves, foraminifers, gastropods, crinoids, bryozoans, echinoids, calcareous dinocysts (Fig. 7) and calcareous sponges are abundant whereas siliceous sponges are less frequent. Ostracod carapaces, ophiuroid ossicles, and G. alpina also appear.

The second microfacies comprises numerous individual specimens of Crescentiella sometimes connected with microbial crusts, peloids and small bioclasts. Some Crescentiella specimens are up to $1.2-\mathrm{cm}$ high. In the studied 
Table 2 List of studied exotic samples including facies types, results of palynological analysis and age (based on microfossil assemblages and, in some samples, calcareous dinoflagellate assemblages)

\begin{tabular}{|c|c|c|c|}
\hline Sample & Facies type & Palynological analysis & Age of the sample \\
\hline $\mathrm{S} 1 / 5$ & FT 1 & - & Oxfordian \\
\hline $\mathrm{S} 2 / 8$ & FT 1 & - & Oxfordian \\
\hline S5/13 & FT 1 & $+($ Barren $)$ & Lowest Kimmeridgian \\
\hline S9/6 & FT 3 & $+($ Barren $)$ & (Upper?) Oxfordian-lowest Kimmeridgian \\
\hline $\mathrm{S} 10 \mathrm{~B} / 10$ & FT 1 & $+($ Poor $)$ & Oxfordian-Kimmeridgian \\
\hline $\mathrm{S} 13 / 4$ & FT 1 & - & (Upper?) Oxfordian-Kimmeridgian \\
\hline $\mathrm{S} 13 / 5$ & FT 2/FT 1 & $+($ Barren $)$ & Kimmeridgian \\
\hline $\mathrm{S} 13 / 6$ & FT 2 & - & Oxfordian-lowest Kimmeridgian \\
\hline $\mathrm{S} 13 / 7$ & FT 1 & - & (Upper?) Oxfordian-lowest Kimmeridgian \\
\hline $\mathrm{S} 15 / 1$ & FT 1 & - & Oxfordian-lower Kimmeridgian \\
\hline S16/11 & FT 2/FT 1 & - & Oxfordian-lower Kimmeridgian \\
\hline $\mathrm{S} 19 / 20$ & FT 1 & + & Middle Oxfordian-lower Kimmeridgian \\
\hline $\mathrm{S} 19 / 32$ & FT 1 & $+($ Poor $)$ & (Upper?) Oxfordian-lowest Kimmeridgian \\
\hline $\mathrm{S} 28 / 5$ & FT 1 & $+($ Barren $)$ & Middle Oxfordian-lower Kimmeridgian \\
\hline $\mathrm{S} 29 / 1$ & FT 1 & - & Lower Kimmeridgian \\
\hline $\mathrm{S} 29 / 3$ & FT 2 & - & (Upper?) Oxfordian-lower Kimmeridgian \\
\hline $\mathrm{S} 29 / 4$ & FT 3 & - & Close to the Kimmeridgian/Tithonian boundary \\
\hline $\mathrm{S} 29 / 5$ & FT 1 & - & (Upper?) Oxfordian-lowest Kimmeridgian \\
\hline $\mathrm{S} 29 / 7$ & FT 1 & $+($ Barren $)$ & (Upper?) Oxfordian-lowest Kimmeridgian \\
\hline $\mathrm{S} 29 / 11$ & FT 3 & $+($ Barren $)$ & Lowest Kimmeridgian \\
\hline S29/12 & FT 1 & $+($ Barren $)$ & Oxfordian-lowest Kimmeridgian \\
\hline S29/14 & FT 3 & $+($ Barren $)$ & Oxfordian-Kimmeridgian \\
\hline $\mathrm{S} 29 / 15$ & FT 3 & $+($ Barren $)$ & Kimmeridgian \\
\hline $\mathrm{S} 30 / 1$ & clasts of FT 2 in FT 3 & $+($ Barren $)$ & Kimmeridgian \\
\hline $\mathrm{S} 30 / 2$ & FT 1 & $+($ Barren $)$ & Oxfordian-lower Kimmeridgian \\
\hline $\mathrm{S} 30 / 4$ & FT 3 & + & (Upper?) Oxfordian-lowest Kimmeridgian \\
\hline $\mathrm{S} 30 / 5$ & FT 3 & + & (Upper?) Oxfordian-lowest Kimmeridgian \\
\hline $\mathrm{S} 30 / 7$ & FT 3 & $+($ Barren $)$ & Kimmeridgian \\
\hline $\mathrm{S} 30 / 9$ & FT 3 & - & Kimmeridgian? \\
\hline S30/18 & FT $1 /$ FT 3 & + & Lowest Kimmeridgian \\
\hline
\end{tabular}

deposits, Crescentiella morphotypes are formed by encrustation or symbiosis between nubecularid foraminifers or enigmatic, spar-filled, tube-shaped structures and microbial envelopes (cf. Senowbari-Daryan et al. 2008; Schlagintweit and Gawlick 2008; Pleş et al. 2017; Krajewski and Schlagintweit 2018). Within the Crescentiella laminae, foraminifers and fine bioclasts are observed. Among bioclasts, small calcified sponges, gastropods, foraminifers, calcareous dinocysts and echinoids are encountered (Fig. 4e). Foraminifers in FT 2 facies are represented by calcareous (Lenticulina, Spirillina, Rumanolina, Cornuspira, Bullopora, nodosarids, epistominids, Ophthalmidium and other miliolids; see: Fig. 6o, p) prevailing over agglutinated forms (such as Protomarssonella and Textularia). Less common are planktonic "globuligerinids" (Fig. 6r). In larger extraclasts, fragments of FT 2 sediments occur as clasts within the FT 3 sediments (see FT 3 description). In the FT 2 facies, dolomitization and silicification processes are common. In the matrix, dolomite forms mainly a dense mosaic of subhedral to anhedral crystals.

\section{FT 3: Fine-grained biodetrital limestones with Saccocoma}

Macroscopic observations reveal that the FT 3 facies-finegrained biodetrital limestones with Saccocoma-is represented by gray or dark-gray, pelitic and siliceous-pelitic limestones. Three microfacies types were distinguished: (i) filamentous-Saccocoma wackestones, (ii) spicule-Saccocoma wackestones and (iii) crinoid-Saccocoma packstones-wackestones (Fig. 5).

The first type embraces numerous thin filaments, radiolarians, and fragments of the planktonic crinoid Saccocoma sp. onto which the syntaxial calcite cement commonly grows (Fig. 5a, b).

The second microfacies contains numerous bioclasts: calcified sponge spicules and Saccocoma fragments but also echinoid plates, radiolarians, ophiuroid ossicles, 

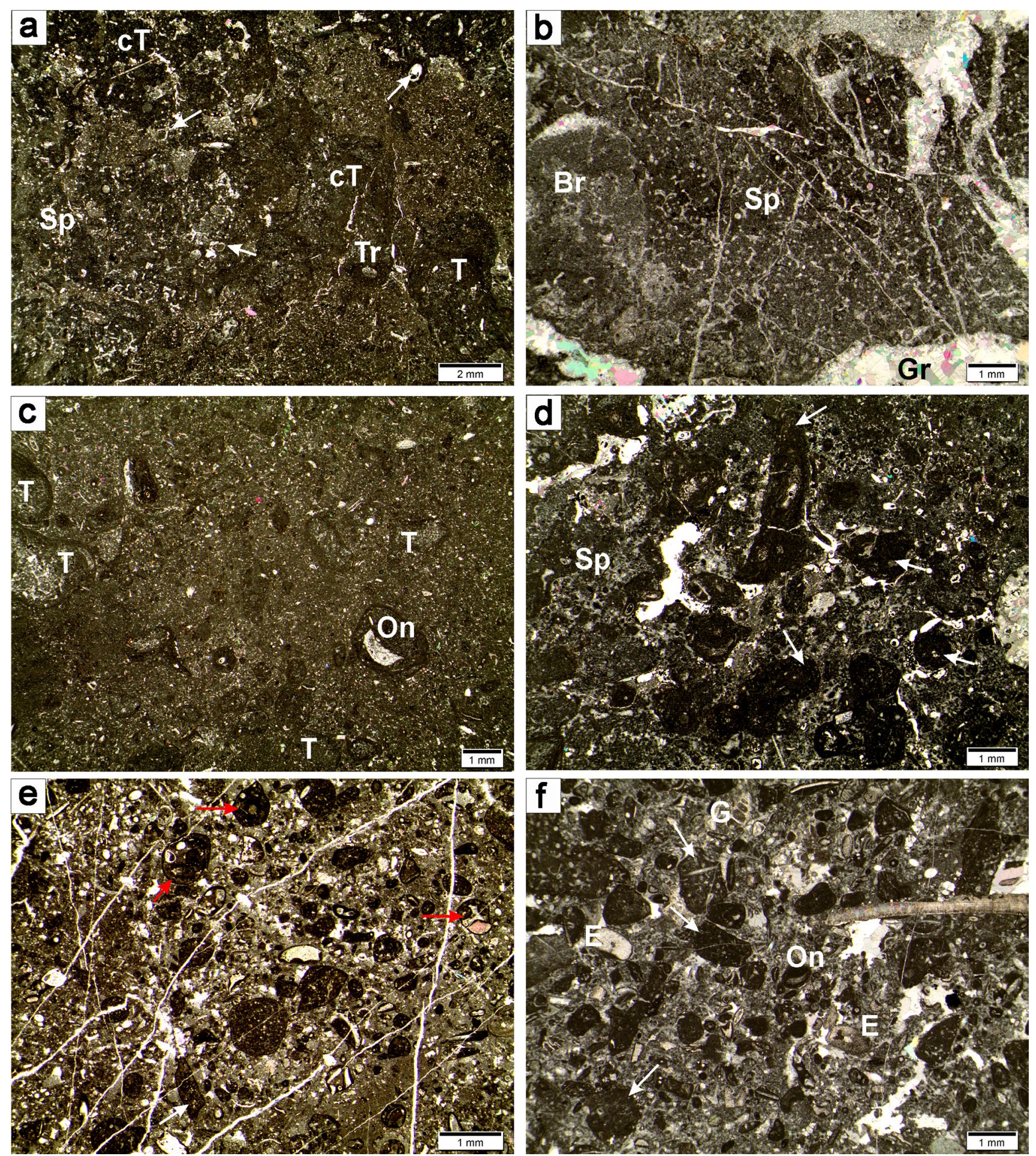

Fig. 4 Microfacies from exotic clasts (photo: M. Krajewski). a Sponge-microbial floatstone with clotted thrombolite (cT) on the outer part of sponge (Sp), tuberoid (T), serpulids (arrows) and Terebella (Tr), FT 1, sample S13/4. b Sponge-microbial framestone; sponge (Sp) with geopetal infilling in the center and boring $(\mathrm{Br})$ on the left side and growth cavity (Gr), FT 1, sample S28/5. c Finegrained wackestone with numerous tuberoids (T) and peloids, FT 1,

sample S10B/10. d Crescentiella-peloidal wackestone, Crescentiella (arrows), locally also bindstone (left side) with calcareous sponge (Sp), FT 2, sample S13/6. Intraclastic-oncoid wackestone-floatstone with intraclasts (white arrows), echinoids (E), oncoids (On), gastropods (G) and aggregate grains (red arrows), FT 2, samples S13/5 (e) and $\mathrm{S} 16 / 11(\mathbf{f})$ 

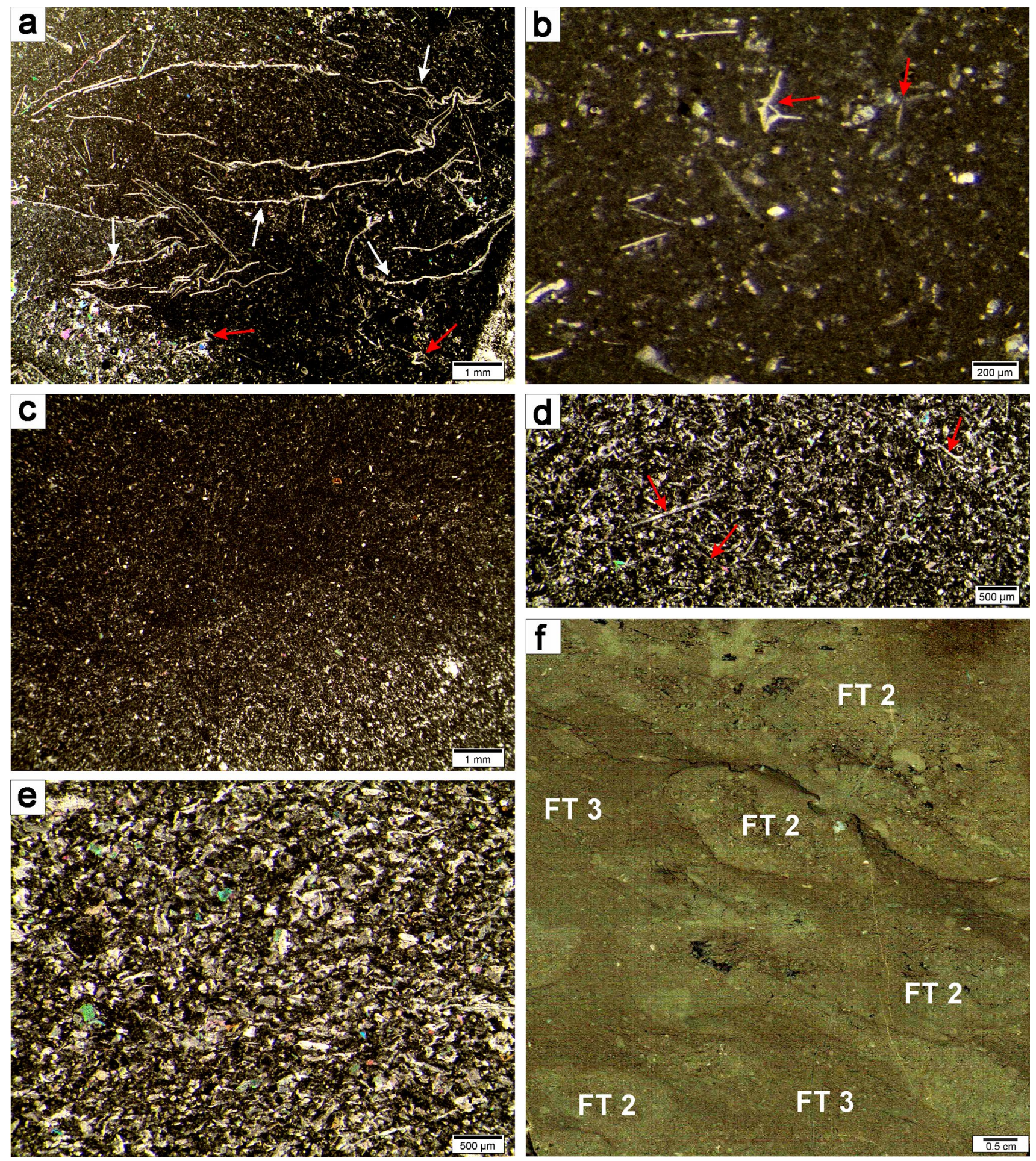

FT 2

Fig. 5 Microfacies from exotic clasts (photo: M. Krajewski). a Filamentous-Saccocoma wackestone with Saccocoma (red arrows) and filaments (white arrows), FT 3, sample S30/9. b Spicule-Saccocoma wackestone, FT 3, sample S29/4. Spicule-Saccocoma wackestonepackstone, spicules (red arrows) FT 3, samples S30/4 (c) and S29/15

(d). e Crinoid-Saccocoma packstone, FT 3, sample S29/14. f Polished slab of exotic clast with redeposited clasts of oncoid-intraclastCrescentiella limestone representing FT 2 within fine-grained biodetrital limestone (FT 3), sample S30/1 
Table 3 Facies and microfacies types

\begin{tabular}{|c|c|c|}
\hline Facies type & Microfacies & Depositional environment \\
\hline FT 1: sponge-microbial limestones & $\begin{array}{l}\text { Sponge-microbial framestones-floatstones } \\
\text { Fine-grained bioclastic wackestones-packstones }\end{array}$ & $\begin{array}{l}\text { Low- to moderate-energy } \\
\text { mid ramp }\end{array}$ \\
\hline FT 2: oncoid-intraclastic-Crescentiella limestones & $\begin{array}{l}\text { Oncoid-intraclast floatstones-wackestones } \\
\text { Crescentiella-peloidal wackestones, less commonly } \\
\text { also bindstones }\end{array}$ & Moderate-energy mid ramp \\
\hline FT 3: fine-grained, biodetrital limestones with Saccocoma & $\begin{array}{l}\text { Filamentous-Saccocoma wackestones } \\
\text { Spicule-Saccocoma } \text { wackestones } \\
\text { Crinoid-Saccocoma } \text { packstones-wackestones }\end{array}$ & Low-energy outer ramp \\
\hline
\end{tabular}

foraminifers, fragments of crinoids and aptychs with microborings (Fig. 5d).

The third microfacies is dominated by various, densely packed fragments of crinoids (Fig. 5e). Foraminifers in FT 3 facies are less diversified compared to both FT 1 and FT 2, and are dominated by calcareous Spirillina, Lenticulina, Rumanolina, Neotrocholina and nodosarids (Fig. 6s, t). Agglutinated foraminifers (e.g., Protomarssonella; see Fig. 6u) are less common, and planktonic foraminifers appear only occasionally. Calcareous dinocysts (Fig. 7) are numerous, and G. alpina, holothurian sclerites and ostracod carapaces are also present. Graded bedding is observed in some samples: crinoid packstones dominate in the bottom part (Fig. 5e) and grade up the sequence into wackestones, rarely to mudstones (Fig. 5c). Sometimes, large exotic clasts contain not only the FT 3 facies but also irregular clasts, 1.5-3-cm thick, formed by oncoid-bivalve-bioclastic grainstones-packstones corresponding to the FT 2 facies (Fig. 5f). The size of the clasts exceeds several centimeters, but some of them can be larger than the exotics. The clasts were deposited orderly, with parallelly arranged longer axes. Based on the position of geopetal infillings in relation to inclination of longer axes of the clasts and the thin bivalve shells in the FT 3 facies, it can be concluded that these deposits were laid down in a slope setting. Some parts of sediments were silicified with cryptocrystalline silica growing mainly in the matrix.

\section{Palynological analysis}

From 18 studied exotic clasts, only four yielded palynological organic matter suitable for further studies: S19/20, S30/4, S30/5, and S30/18 (two other samples, S10B/10 and S19/32 yielded very low numbers of poorly preserved dinoflagellate cysts). These four clasts are dark-gray to black, micritic limestones. In contrast to the other clasts, which appeared to be barren, these samples contained high amounts of palynological organic matter composed mainly of dinoflagellate cysts (Fig. 8; for full list of taxa in samples see Electronic Supplementary Material). The remaining barren clasts are mainly light-colored (beige, gray-creamish, pale grayish) limestones. However, it is noteworthy that some barren clasts are dark-colored limestones (e.g., S9/6, S30/7), identical with the productive ones.

The four productive samples showed similar palynofacies dominated by dinoflagellate cysts and black, opaque phytoclasts. The palynomorphs differ significantly both in preservation and taxonomical composition of the assemblages. The sample S19/20 yielded very well-preserved dinoflagellate cysts with predominating Systematophora (S. areolata, S. valensii, S. varispinosa, and $S$. vestita). The three further samples: S30/4, S30/5, and S30/18 yielded similar, slightly worse-preserved specimens than in sample S19/20, assemblages with frequent Sentusidinium spp., Leptodinium subtile and Gonyaulacysta jurassica. Foraminifers organic linings occur in these samples.

\section{Discussion}

\section{Age of studied exotics}

\section{Calcareous microfossils}

Based on the foraminifers and calcareous dinocysts, the age of studied samples can be generally determined as Oxfordian and Kimmeridgian (Table 2; see also Electronic Supplementary Material). Foraminifers and calcareous dinocysts are the biostratigraphically most significant microfossils of studied exotics (Figs. 6, 7). The majority of the identified foraminifers have relatively wide known stratigraphic ranges (after: Olszewska et al. 2011, 2012; Olszewska 2014, and references therein) (Fig. 9); hence, precise age determinations are impossible. The planktonic foraminifers- "globuligerinids"-are typical components of the Oxfordian calcareous rocks in southern Poland, but they can also appear in the Kimmeridgian and the Tithonian. Determination of the planktonic species in thin sections is problematic but the occurrence of specimens, which can be classified as Globuligerina oxfordiana, suggests an Oxfordian-earliest Kimmeridgian age (e.g., Olszewska et al. 2011, 2012; Olszewska 2014). "Compactogerina stellapolaris” is 

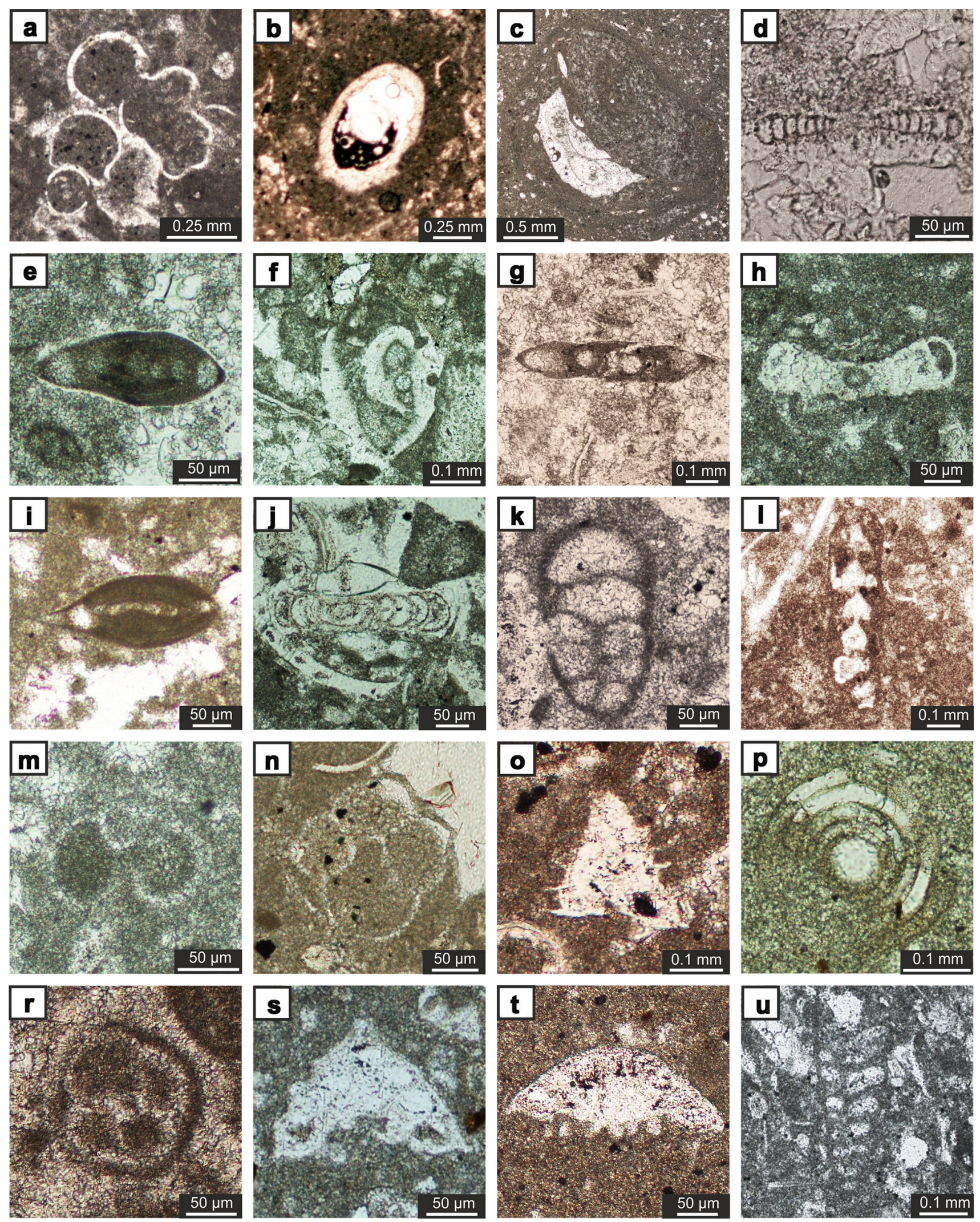
4Fig. 6 Microfossils, mainly foraminifera, from the exotic clasts (photo: J. Kowal-Kasprzyk), a Bullopora tuberculata (S16/11). b Terebella lapilloides (S13/4). c Crescentiella morronensis with encrustations of nubecularid foraminifer and probably serpulid worms (S10B/10). d Spirillina tenuissima (S1/5). e Ophthalmidium pseudocarinatum (S5/13). f Protopeneroplis striata (S5/13). g Ophthalmidium bolgradensis (S2/8). h Spirillina andreae (S5/13). i Ophthalmidium strumosum (S19/32). j Spirillina elongata (S5/13). $\mathbf{k}$ Eomarssonella paraconica (S2/8). I Ammobaculites irregularis (S13/7). m Globuligerina oxfordiana (S29/7). n Globuligerina oxfordiana (S30/18). o Rumanolina feifeli seiboldi (S13/6). p "Cornuspira eichbergensis" (S29/3). r "Compactogerina stellapolaris" (S30/1). s Rumanolina feifeli feifeli (S30/5). t Neotrocholina valdensis (S29/4). u Protomarssonella jurassica (S9/6)

observed in the Kimmeridgian rocks from southern Poland, but it should be mentioned that Gradstein (2017) supposes a Late Cenozoic age of its holotype; thus, the Jurassic forms should be revised and they cannot be treated as a valid stratigraphic marker.

The calcareous dinocysts, common in the studied samples (Fig. 7), can also be used for stratigraphy, but it must be noted that their ranges may vary between various sedimentary basins; hence, the widest known ranges (after Borza 1969; Řehánek and Cecca 1993; Řehánek and Heliasz 1993; Řeháková 2000; Olszewska 2014; Olszewska et al. 2011, 2012 and references therein) are here applied.

\section{Organic-walled dinoflagellate cysts}

The most probable age of the organic-walled dinoflagellate cysts assemblages from the four productive samples is middle Oxfordian to earliest late Kimmeridgian. The majority of determined organic-walled dinoflagellate cysts occurs in the Upper Jurassic deposits, mainly in the Oxfordian-Kimmeridgian (see Table 2 and Fig. 9). The lower age range of the studied samples is defined by the occurrence of Leptodinium subtile, Endoscrinium luridum, and Glossodinium dimorphum. The oldest occurrences of these species are known from the lower and middle Oxfordian of the Boreal Realm from the lowermost Oxfordian Cordatum Ammonite Zone (L. subtile), the lower middle Oxfordian Densiplicatum Ammonite Zone (E. luridum), and the upper middle Oxfordian Tenuiserratum Ammonite Zone (G. dimorphum; Riding and Thomas 1992). The upper range, in turn, can be determined by the presence of a few species that are the most common in the uppermost lower Kimmeridgian to lower upper Kimmeridgian ammonite zones Autissiodorensis and Elegans: E. luridum, Gonyaulacysta jurassica, and Rhynchodiniopsis cladophora (Riding and Thomas 1992).

The above-described assemblages allow us to correlate the productive exotics with the Scriniodinium crystallinum and/or Endoscrinium luridum dinoflagellate cyst zones. These zones were established in the North Sea Basin (Woollam and Riding 1983, subsequently emended by Riding and
Thomas 1988 and Poulsen 1991). Poulsen (1992, 1993, 1996) successfully applied this zonal scheme also in Poland based on similarity of coeval assemblages from central and southern (but not southernmost) Poland (i.e., in the area between the Subboreal and the Submediterranean provinces). Among the dinoflagellate cyst assemblages described by this author from Poland, the most similar ones compared to those found in the exotics are species correlated with the Subzone c of the Scriniodinium crystallinum Zone (i.e., the uppermost Oxfordian Rosenkrantzi Ammonite Zone). The communities are dominated by Systematophora areolata, Gonyaulacysta jurassica, and Sentusidinium rioultii, with frequent Epiplosphaera and Rhynchodiniopsis cladophora (Poulsen 1991). Assemblages from the younger strata in Poland (Hypselocylcum-Divisum zones) not only include most of the species found in the exotics, but also they contain characteristic and frequent specimens of $\mathrm{Cri}$ broperidinium and Subtilisphaera? inaffecta that are absent from the exotics. Frequent Cribroperidinium (C. venustum) associated with Escharisphaeridia mantellii, Atlantodinium jurassicum and Amphorula dodekovae (all missing in the exotics) were described from the lower Kimmeridgian strata of the surroundings of the Holy-Cross Mountains (Gedl and Ziaja 2004).

\section{Paleoenvironment}

\section{Facies interpretation}

The studied facies are related to mid-ramp to outer-ramp settings. Usually, on the northern Tethys shelf, the Oxfordian-Kimmeridgian sponge-microbial limestones (FT 1) are interpreted as distal mid-ramp facies, i.e., deposited mostly in a low-energy, nutrient-rich environment. The FT 1 formed at estimated depths of some tens of meters, between the fairweather and the storm waves bases (e.g., Keupp et al. 1993; Leinfelder et al. 1996; Olóriz et al. 2003; Olivier et al. 2003; Reolid et al. 2005; Matyszkiewicz et al. 2006, 2012; Krajewski et al. 2016, 2018; Olchowy et al. 2019).

The oncoid-intraclast-Crescentiella limestones (FT 2) dominated by various coated grains, bioclasts and intraclasts with numerous Crescentiella are commonly observed in many parts of Upper Jurassic, open marine, shallow-water platforms (above the storm wave base i.e., around 40-60 m depth) of the Tethyan Realm in the Central Europe (e.g., Leinfelder et al. 1996; Krajewski and Olszewska 2006; Matyszkiewicz et al. 2006, 2012; Schlagintweit and Gawlick 2008; Hoffmann et al. 2017; Pleş et al. 2017; Krajewski and Schlagintweit 2018; and references therein). On the northern Tethyan shelf area, such associations are common in a mid-ramp setting (e.g., Leinfelder et al. 1996; SenowbariDaryan et al. 2008; Krajewski et al. 2016, 2018; Olchowy et al. 2019). Both the oncoids and the aggregate coated 

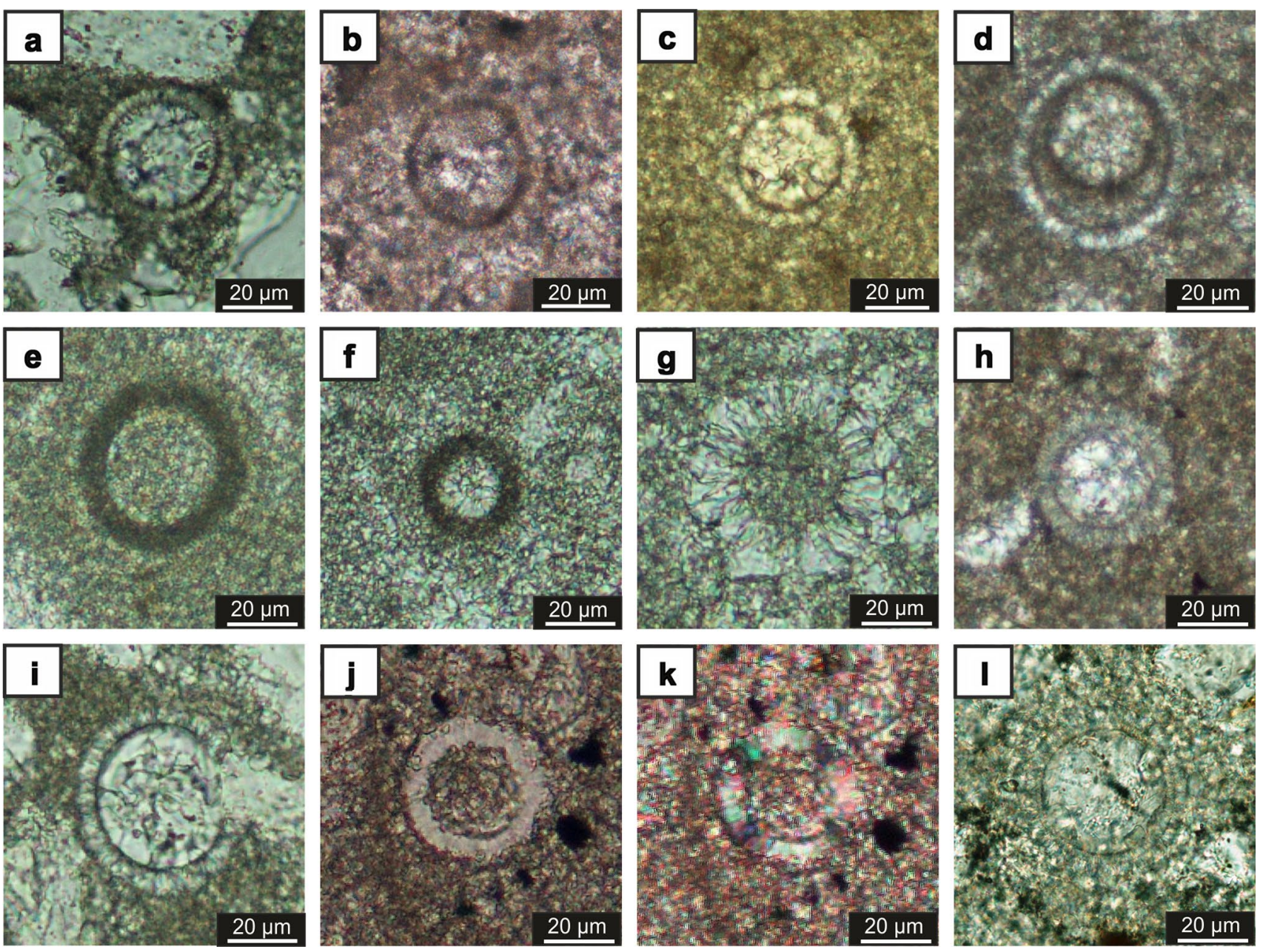

Fig. 7 Calcareous dinoflagellate cysts from the exotic clasts (photo: J. Kowal-Kasprzyk). a Colomisphaera fibrata (S5/13). b Committosphaera czestochowiensis (S16/11). c Colomisphaera lapidosa (S29/12). d Crustocadosina semiradiata semiradiata (S29/11). e Crustocadosina semiradiata semiradiata (S30/1). f Cadosina par-

grains indicate an environment close to the depth of the fair-weather wave base. The presence of type I and type II oncoids (e.g., Védrine et al. 2007) suggests a depositional environment of an open-sea, mid-inner ramp with moderate water energy.

The fine-grained biodetrital limestones (FT 3) facies is represented by fine-grained pelagic limestones. These deposits correspond very well to spiculite wackestones (standard microfacies-SMF 1; SMF's after Flügel 2004), microbioclastic peloidal calcisiltites representing the SMF 2 microfacies, and pelagic mudstones-wackestones representing the SMF 3 microfacies. The FT 3 was deposited in a deeper part of the basin in an outer-ramp setting (e.g., Flügel 2004). A part of Saccocoma-dominated sediments was primarily deposited from suspension on a sea floor of distinct relief and then became subsequently transported by turbidity currents; hence, they show graded bedding, typical

vula (S30/7). g Colomisphaera carpathica (S5/13). h Colomisphaera minutissima (S29/11). i Colomisphaera pieniniensis (S30/1). j Stomiosphaera moluccana (S13/5). k Stomiosphaera moluccana (S13/5) XPL. I Carpistomiosphaera borzai (S29/4)

of calciturbidites (e.g., Matyszkiewicz 1996, 1997). The FT 2 facies forming clasts within the FT 3 sediments represents the gravity-flow material presumably redeposited, e.g., as debris flows from more shallow settings located close to the fair-weather wave base of moderate water energy.

\section{Palynological analysis}

The palynological analysis of 18 exotic limestones shows that they were deposited in various environments manifested by the presence or absence of organic-walled microfossils (palynomorphs). A factor responsible for this difference was likely the oxygen level in bottom waters. Well-preserved organic-walled dinoflagellate cysts from some exotics settled down under dysoxic bottom water conditions that enabled their preservation. The barren exotics (mainly pale-colored lithologies) represent deposits that presumably accumulated 

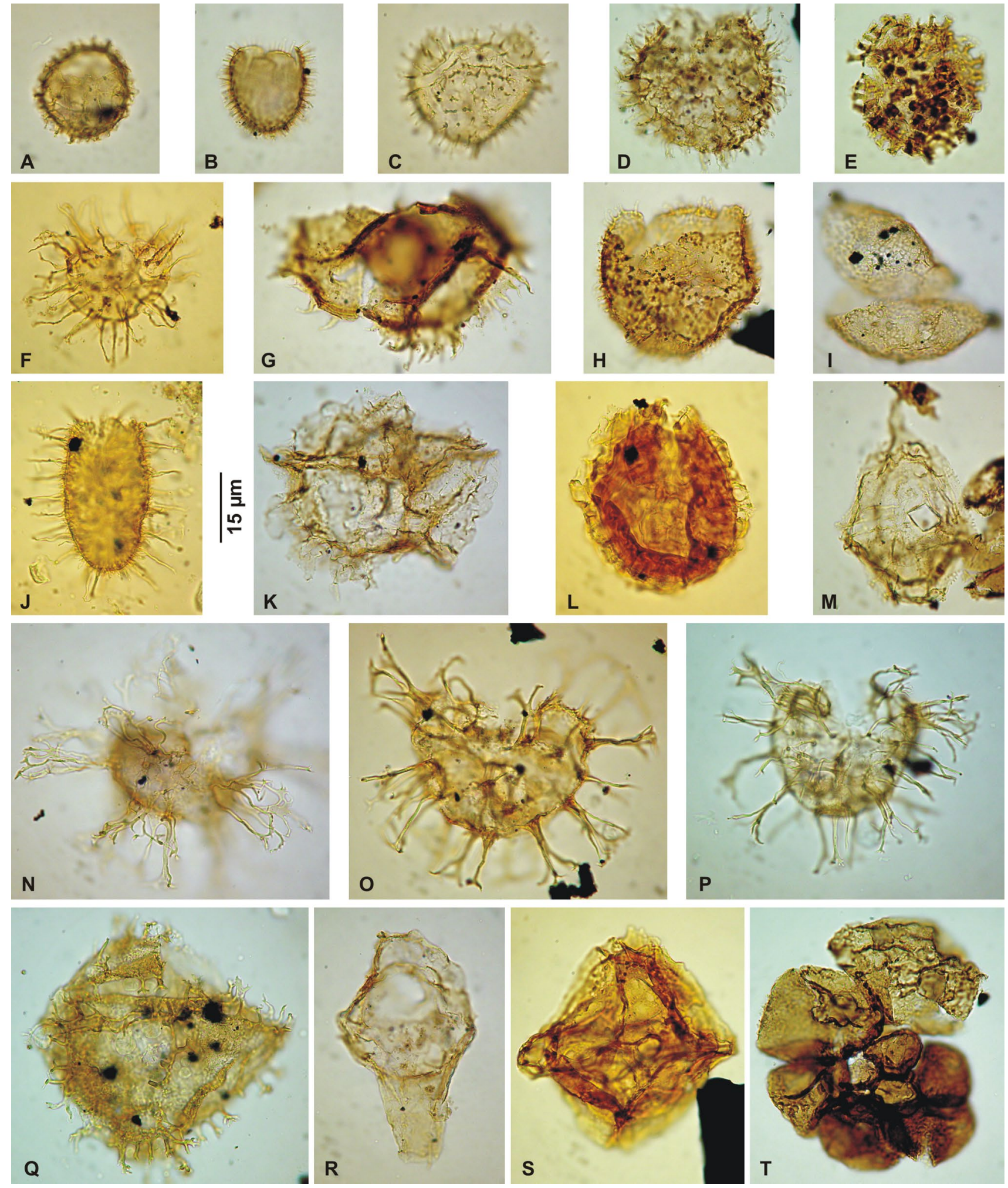

Fig. 8 Organic-walled dinoflagellate cysts and foraminifera organic lining from exotic clasts (photo: P. Gedl). Scale bar refers to all photomicrographs. a Ellipsoidictyum cinctum (S19/20). b Sentusidinium sp. (S19/20). c Epiplosphaera areolata (S19/20). d Epiplosphaera sp. (S30/4). e Chlamydophorella nyei (S30/18). f Cleistosphaeridium iaculigerum (S30/4). $\mathbf{g}$ poorly preserved specimen of Ctenidodinium (S30/4). h Sentusidinium rioultii (S30/5). i Mendicodinium?
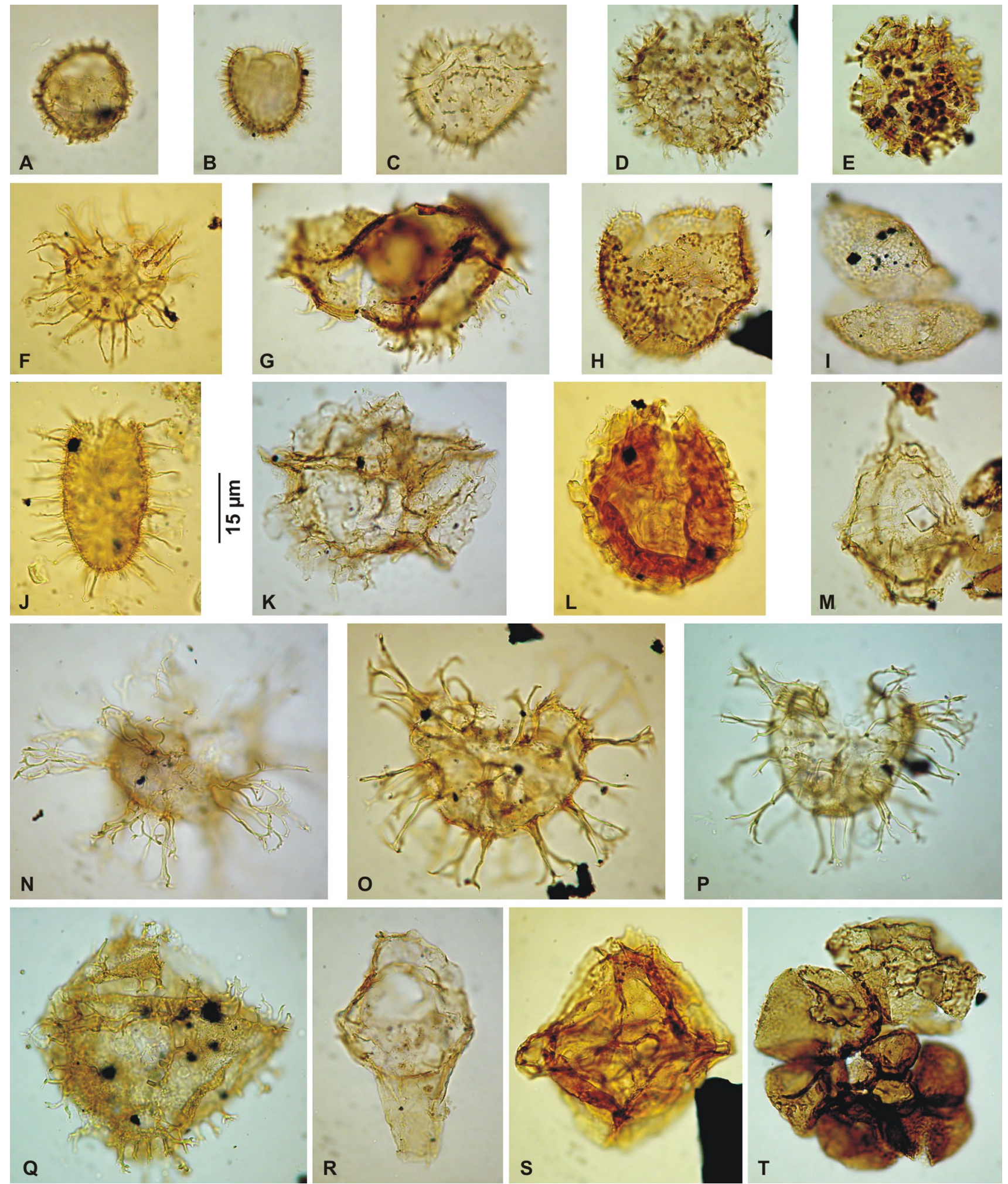

sp. B of Brenner (1988) (S19/20). j Prolixosphaeridium mixtispinosum (S19/20). k Glossodinium dimorphum (S19/20). I Scriniodinium dictyotum (S19/20). m Gonyaulacysta jurassica (S30/5). n Systematophora penicillata (S19/20). o Systematophora valensii (S19/20). p Systematophora areolata (S19/20). q Rhynchodiniopsis cladophora (S19/20). r Tubotuberella apatela (S30/4). s Endoscrinium luridum (S30/5). t Foraminifera organic lining (S30/5) 


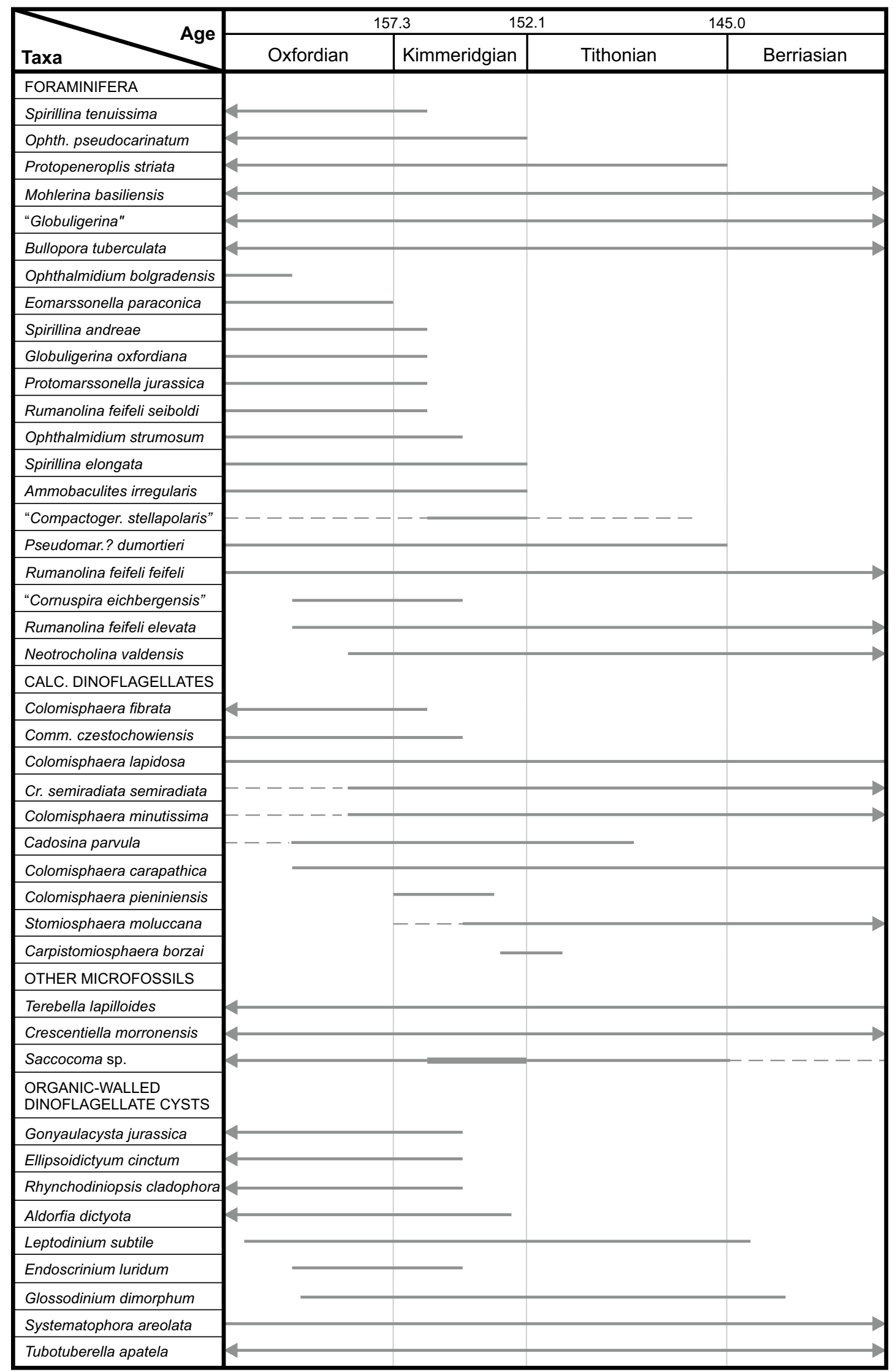


४Fig. 9 Stratigraphically significant calcareous microfossils-mainly foraminifers and calcareous dinoflagellate cysts-identified in the studied samples and their known age ranges (after Borza 1969; Řehánek and Cecca 1993; Řehánek and Heliasz 1993; Řeháková 2000; Olszewska et al. 2011, 2012; Olszewska 2014 and references therein), and stratigraphically important organic-walled dinoflagellate cysts and their age ranges (after Riding and Thomas 1988, 1992; Poulsen 1991, 1992, 1993, 1996)

under well-ventilated, oxygen-rich bottom water regime. The nature of the studied samples—isolated exotics—precludes the determination of disoxic/anoxic bottom water conditions as a regional event during the late Oxfordian-early Kimmeridgian or as a reflection of only local conditions.

The palynofacies composed chiefly of dinoflagellate cysts with only minor proportions of terrestrial phytoclasts as well as the taxonomic composition of the organic-walled dinoflagellate cyst assemblages suggest a fully marine sedimentary setting with limited land influences. The presence of organic foraminiferal linings additionally confirms the marine environment.

The comparison of the exotic assemblages with the Oxfordian-Kimmeridgian ones from epicontinental deposits of central and southern Poland reveals a similarity to the Oxfordian assemblages from the offshore facies of southern Poland (see Poulsen 1993). The Kimmeridgian assemblages from the shallow-water, near-shore environments of central Poland are different. They are rich in Cribroperidinium (and morphologically similar species like Occisucysta and Tehamadinium) and other characteristic forms like Atlantodinium jurassicum and Amphorula dodekovae (see Poulsen 1996; Gedl and Ziaja 2004), which are rare or missing in the exotic material. The Cribroperidinium and similar morphotypes (e.g., Trichodinium and Apteodinium) occur also in the rather shallow-water Tithonian Vendryně Formation (see chapter 2.1), and they are associated with Systematop hora/Hystrichosphaerina and Endoscrinium/Scriniodinium morphotypes (Gedl and Szydło 2001). This may suggest that the motile stages of assemblages from exotics inhabited more offshore waters, similar to those which predominated in the epicontinental Oxfordian in southern Poland, rather than shallow, near-shore areas.

The offshore preferences of the motile stages of dinoflagellate cysts from the studied exotics can also be confirmed by a comparison with the Callovian-Oxfordian assemblages from the Grajcarek Unit (Magura Basin) and the Branisko Nappe of the Inner Carpathians. They yielded frequent specimens of Systematophora and proximochorate gonyaulacoids like Sentusidinium and Epiplosphaera, and lack Cribroperidinium morphotypes (see Gedl 2008).

It should be noted that three samples (S30/4, S30/5 and S30/18) with similar, taxonomically diversified dinoflagellate cyst assemblages represent the deepest facies FT 3. The sample S19/20 with a Systematophora-dominated assemblage represents a shallower facies FT 1. However, there are too few data to draw further conclusions on palaeoenvironmental preferences.

\section{Comparison of clasts and adjacent epicontinental deposits}

The studied facies are similar to facies types known from the northern shelf area of the Western Tethys. Both the FT 1 and FT 2 facies show similarities to spongiolitic or sponge-microbial and biodetrital limestones facies with bioclasts, oncoids, intraclasts and Crescentiella, which are widely distributed over the northern shelf of the Western Tethys (e.g., southern Poland and southern Germany; e.g., Trammer 1989; Leinfelder et al. 1996; Matyszkiewicz 1997; Schmid et al. 2001; Matyszkiewicz et al. 2012 and references therein). The area closest to the sampling sites of in situ Oxfordian-lower Kimmeridgian facies occurrences is the southern part of the Kraków-Częstochowa Upland, nowadays some $15 \mathrm{~km}$ distant from these exposures (Fig. 1; e.g., Matyszkiewicz et al. 2012, 2016; Krajewski et al. 2018). It must be emphasized, however, that due to tectonic transport of the Carpathian nappes, this distance in the Late Jurassic was at least $60-70 \mathrm{~km}$, according to the results of deep drillings (see Wdowiarz 1976; Ślączka et al. 2006). This facies type dominates also in the Oxfordian strata described from the basement of the Carpathian Foredeep (e.g., Matyja 2009; Krajewski et al. 2011a; Morycowa and Moryc 2011). Moreover, deposits similar to the FT 1 facies are known from the Tithonian strata found in the basement of the Carpathian Foredeep (e.g., Matyja 2009; Krajewski et al. 2011a) and from the Tithonian organodetrital conglomerates embedded in the Cieszyn Limestone (e.g., Matyszkiewicz and Słomka 1994, 2004). In the southern part of the Kraków-Częstochowa Upland, the sponge-microbial facies occurs most widely in the upper Oxfordian (mainly Bifurcatus Zone) and/or in the lower Kimmeridgian deposits (mainly Planula Zone) (e.g., Matyszkiewicz et al. 2012; Krajewski et al. 2018). In this area, the rocks developed as medium- or thick-bedded limestones, together with massive, low-relief, segment or frame reefs (sensu Riding 2002), and represent vast reef complexes (e.g., Matyszkiewicz et al. 2006, 2012; Krajewski et al. 2018). Moreover, this facies is also dominating in clasts and blocks (up to several tens of centimeters in diameter) that occur in gravity-flow deposits (debris flows and olistoliths) developed in the southwestern part of the Kraków-Częstochowa Upland (e.g., Matyszkiewicz 1996; Woźniak et al. 2018; Woźniak and Bania 2019). Due to synsedimentary tectonics, such debrites were deposited along the slopes of the ridges that followed the Kraków-Lubliniec Fault Zone-a vast tectonic structure that was active in the Mesozoic and separated the Małopolska and the Silesian terranes (e.g., Żelaźniewicz et al. 2011). 
It is worth noting that similar sponge-microbial facies are observed also in the Tithonian exotic limestones known from the same study area (Kowal-Kasprzyk 2016, 2018). It may suggest that the sponge-microbial sedimentation had proceeded along the margins of the proto-Silesian basin at least until the end of the Jurassic. A similar feature is observed in the exotics from the Pieniny Klippen Belt, which represents the remnants of the Andrusov Ridge (Matyszkiewicz et al. 2004).

In case of the Kimmeridgian FT 3 facies, the closest analogs can be found in the basement of the Carpathian Foredeep, in Poland, and in Ukraine (Krajewski et al. 2011a,b; Olszewska et al. 2012). More rarely, such facies were observed in the extra-Carpathian central and southern Poland, i.e., in the northern Tethys shelf area (lower Kimmeridgian Platynota Zone) (e.g., Matyszkiewicz 1996; Krajewski et al. 2014; Woźniak and Bania 2019). In the Inner Carpathians, similar deposits, although containing filamentous-Saccocoma microfacies (wackestones-packstones), were described from the lower Kimmeridgian fine-grained pelagic facies of the Krížna Unit in the Tatra Mts. (e.g., Jach et al. 2012). Analogous, Kimmeridgian dark-gray limestone facies represented by spiculitic Saccocoma wackestones-mudstones with filaments and deposited as calciturbidites in the deep shelf and slope settings, was described from the basement of the Carpathian Foredeep of the western Ukraine, along the marginal ridge of the East European Platform (Krajewski et al. 2011b). Moreover, such rocks were encountered also in a few outcrops near the edges of tectonic ridges (margin of the Małopolska and Upper Silesian terranes) located in the southernmost part of the Kraków-Częstochowa Upland (Matyszkiewicz 1996, 1997) where they constitute the northern margin of the Carpathian Foredeep. These deposits are partly silicified, finegrained pelagic packstones, wackestones and mudstones with peloids, small bioclasts, echinoderms, and loose, variously shaped remains of Saccocoma (Matyszkiewicz 1996), which show normal grading, rarely also cross-lamination. These rocks can be interpreted as calciturbidites laid down along the marginal parts of tectonic ridges and are genetically related to synsedimentary tectonic events. Their age was determined as lower Kimmeridgian (Platynota Zone). Matyszkiewicz (1996) described the outcrops of characteristic, 20-m-thick sequences, in which the lower Kimmeridgian reefs or biostromes (previously identified as the upper Oxfordian Planula Zone) are covered with calciturbidites with Saccocoma, identical with the FT 3 facies as well as by debris flows composed of blocks and clasts similar to the FT 2 facies, rarely even to the FT 1 one. These facies document the final stage of development of the middle Oxfordian-lower Kimmeridgian reef complexes in the Polish part of the Tethys shelf, i.e., a submersion of the platform followed by synsedimentary tectonic disturbances, which both reflect the transregional geological events. A similar and contemporaneous sedimentary sequence was described from the Lochen area (Schwäbische Alb) in southern Germany (Keupp and Matyszkiewicz 1997; Matyszkiewicz 1997). Hence, it can be concluded that both the development and the depositional setting of the studied extraclasts resemble the Oxfordian-lower Kimmeridgian sedimentary succession in the adjacent southern part of the Kraków-Częstochowa Upland.

The Oxfordian deposits found in the klippes from both the Andrychów and the Kruhel areas as well as from the exotic block in Bachowice are also comparable-mainly due to the occurrence of epicontinental faunal assemblages (e.g., Olszewska and Wieczorek 2001; Oszewska et al. 2011) - to rocks from the northwestern Tethyan shelf. Similar faunal assemblages are also known from these parts of the Carpathian Foredeep, which were covered by the Carpathian overthrust and, thus, are known only from deep drillings (e.g., Olszewska in Wójcik et al. 2006).

\section{Oxfordian-Kimmeridgian paleogeography}

During the Oxfordian-Kimmeridgian, the study area was part of the southern margin of the northern Tethys shelf known as the Peri-Tethys, north of the Alpine Tethys (Fig. 10). The investigated exotic rocks indicate that during the Oxfordian, a broad carbonate platform was developed, similarly as on the adjacent Precarpathian Foredeep basement and the Kraków-Częstochowa Upland. Microbial-sponge and microbial-Crescentiella facies formed local, broad reef complexes on the platform. Particularly, intense reef development in the southern margin of the North Tethys shelf took place on uplifted areas associated with marginal parts of the broad tectonic zones separating the terranes (e.g., Upper Silesian and Małopolska terranes; Matyszkiewicz et al. 2006; Krajewski et al. 2018).

The Oxfordian-Kimmeridgian periodic disintegration of the carbonate platform into smaller paleogeographic elements took place during intervals of strong extensional tectonic events. They occurred in the Carpathian area as well as in both central and southern Poland (Kutek 1994; Golonka 2004; Golonka et al. 2008a; Krajewski et al. 2016; Matyszkiewicz et al. 2016). In southern Poland, middle Oxfordian-early Kimmeridgian (Transversarium-Platynota zones) synsedimentary tectonic activity is documented by intense development of gravity-flow deposits (olistoliths, debris flows, calciturbidites) and neptunian dykes along the marginal parts of broad tectonic zones (e.g., Matyszkiewicz 1996; Matyszkiewicz et al. 2006, 2012, 2016; Barski and Mieszkowski 2014; Woźniak et al. 2018; Woźniak and Bania 2019). Synsedimentary tectonics periodically active in the northern Tethyan shelf was related to the opening of the North Atlantic and Tethys oceans. It resulted in the Late 


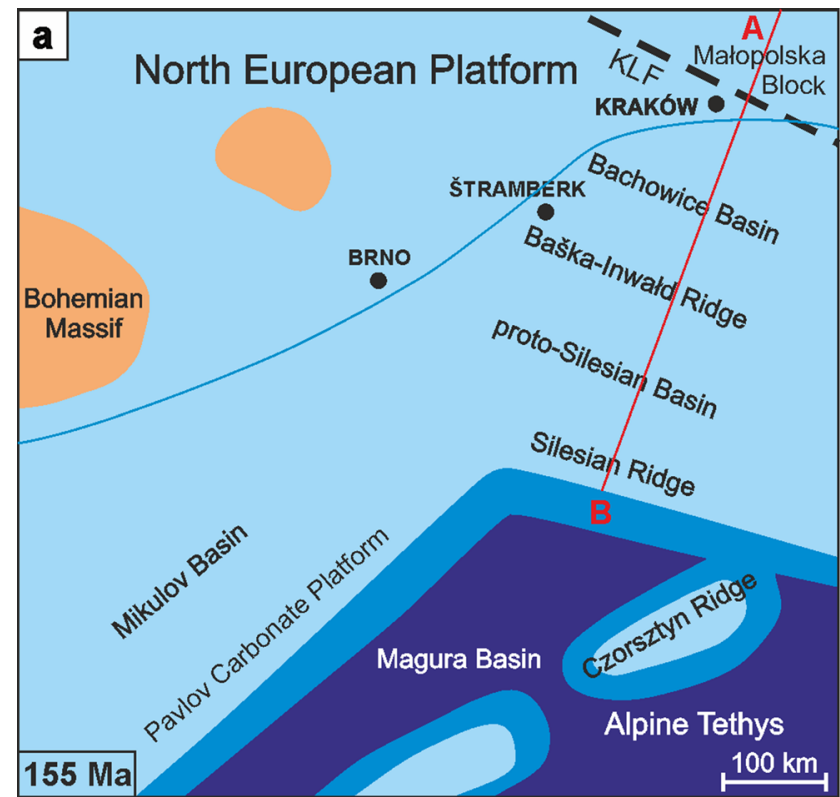

Fig. 10 a Paleogeography of the proto-Silesian (Severin-Moldavidic) Basin and surrounding areas in the Oxfordian-Kimmeridgian (after: Golonka et al. 2006, 2008a, b; Krajewski et al. 2016, somewhat mod-

Jurassic stress-field reorganization, which also included the passive northern margin of the Tethys (e.g., Allenbach 2002; Nieto et al. 2012).

Based on the data from the study area and the adjacent regions, it can be assumed that uplifted and depressed zones in the Western Carpathians were paleogeographic elements as early as in the Oxfordian. Thus, in the late Oxfordian-Kimmeridgian, several paleogeographic elements, related to the origin of the discussed limestones, can be distinguished in the Polish part of southern margin of the North European Platform. The Silesian Ridge, situated between the proto-Silesian (later: Silesian) and the Magura basins, is usually interpreted as an elevated part of the North European Platform margin (e.g., Sikora 1976; Golonka et al. 2006). The Baška-Inwałd Ridge was located between the proto-Silesian and the Bachowice basins (e.g., Książkiewicz 1960, 1965; Olszewska and Wieczorek 2001). According to Golonka et al. (2008a), this ridge originated in the Late Jurassic as a result of thermal uplift preceding the rifting, which involved the opening of the protoSilesian Basin. The enigmatic Bachowice Basin possibly constituted the depressed zone of the North European Platform (Książkiewcz 1956a; Olszewska and Wieczorek 2001; Golonka et al. 2008a), which is indicated by the differences in sedimentation noticeable since the Kimmeridgian (Olszewska et al. 2011).

Both the sedimentation and the facies architecture in the adjacent extra-Carpathian southern Poland may have

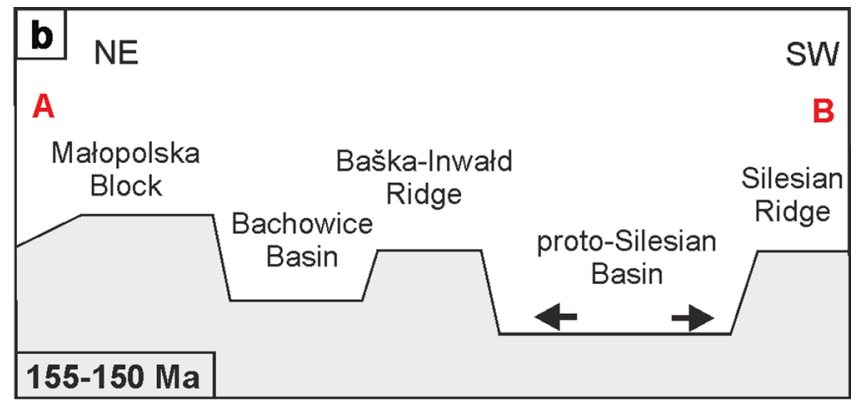

marginal sea

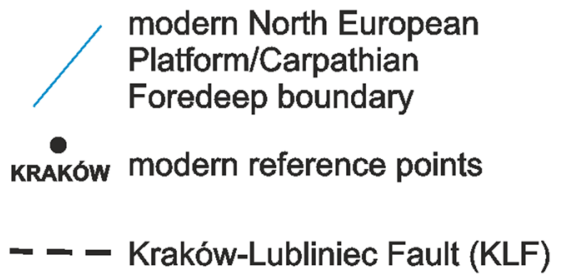

ified). b Position of southern margin of the North European Platform in the Late Jurassic (after: Olszewska and Wieczorek 2001; Krajewski et al. 2016, simplified)

resulted also from the northeastern progradation of rifting from the southern areas towards the northern Tethyan shelf. This process might have generated the northeastern extension of parallel, northwest-southeast-trending swells and basins (e.g., Baška-Inwałd Ridge and Bachowice Basin) developed in the southern segment of the peri-Tethyan part of the platform. For example, Matyszkiewicz (1997) described the southern part of the Kraków-Częstochowa Upland as an elevation of the shelf margin based on the regional facies analysis and the low subsidence caused by magmatic intrusions ascending along the margin of the Małopolska terrane. Also, Krajewski et al. (2016) distinguished an elevated ridge (Kraków-Częstochowa Upland) located in the uplifted southern margin of the Małopolska terrane (Żelaźniewicz et al. 2011; Małopolska Ridge) and a deeper basin embracing the Miechów Depression and the Wieluń Upland.

\section{Source areas of exotic limestones}

The studied exotics originate from the Lower Cretaceous to Eocene flysch strata. In the majority of the studied localities, direct determination of paleotransport direction was impossible, but the general trends in distribution of predominant source areas supplying the Outer Carpathian basins and their changes in time are well known (Książkiewicz 1962; Unrug 1963; Ślączka 1976; Leszczyński 1981). The Silesian Ridge is considered as the most important source area for 
the proto-Silesian and, later on, for the Silesian Basin (e.g., Książkiewicz 1965; Eliáš 1970; Ślączka et al. 2006). The Baška-Inwałd Ridge was the northern source area for the western part of the basin and was active mainly in the Early Cretaceous (e.g., Książkiewicz 1956a, 1965; Matyszkiewicz and Słomka 1994).

The studied localities within the Lower Cretaceous Hradiště Formation are situated close to the northern margin of the Silesian Unit and in the area of the Subsilesian Unit; hence, the exotics were most probably supplied to these basins from the Baška-Inwałd Ridge. During the Late Cretaceous and the Paleocene-Eocene, the detrital material was delivered to the Silesian Basin mainly from the southwest; thus, the exotics described from the Istebna and the Ciężkowice formations most probably originated from the erosion of the Silesian Ridge. The paleotransport indicators were directly analyzed in the field only in the Beskid Mały Mts. (sampling sites S29 and S30) where the exotics occur within the Upper Istebna Beds (Strzeboński et al. 2017). The results are consistent with the general trends described above. However, it must be taken into consideration that some exotics might have been recycled, i.e., reworked from older flysch deposits and resedimented in younger deposits (Książkiewicz 1956b; Matyszkiewicz and Słomka 1994; Cieszkowski et al. 2009; Strzeboński et al. 2017).

It should be noted that some differences are observed between the studied exotics derived from these two source areas. Among the exotics originating probably from the Baška-Inwałd Ridge, both the FT 1 and FT 2 facies prevail, whilst the FT 3 facies dominates in exotics coming presumably from the Silesian Ridge. The amount of study material as well as its dispersion and redeposition hinder some firm conclusions, but these data can suggest that in the sedimentary environment of the Baška-Inwałd Ridge rather the shallower facies were deposited in comparison with the Silesian Ridge area, which was situated further to the south.

During the Miocene tectonic movements, flysch deposits were detached from their original basement and thrusted over Mesozoic rocks of the North European Platform. As a result, today mainly deposits filling the axial parts of the Outer Carpathians basins are observed (e.g., Książkiewicz 1931, 1977; Sikora 1976; Ślączka et al. 2006; see also: Picha et al. 2006; Fig. 6). Due to the future uplift of the ridges followed by their erosion and redeposition of detrital material to the flysch series, the exotic rocks are the only known remnants of the pre-flysch Oxfordian-Kimmeridgian sedimentation in this area.

\section{Conclusions}

- The analysis of exotic clasts from southern Poland revealed new insights into the organic life and sedimentary conditions during the platform phase that preceded the development of the Outer Carpathian flysch basins.

- Micropaleontological and palynological data, and a comparison with epicontinental deposits, generally suggest an Oxfordian-Kimmeridgian age of studied exotic limestones. Also comparisons with other epicontinental deposits are confirming this stratigraphic interval.

- The exotics are defined by three facies types (FT 1-3). The sponge-microbial limestones (FT 1) can be interpreted as a mid-ramp facies, i.e., deposited mostly in a low-energy, nutrient-rich environment. Also, the oncoidintraclast-Crescentiella limestones (FT 2) are related to a mid-ramp setting. The fine-grained biodetrital limestones (FT 3) were possibly deposited in deep shelf or toe-ofslope environments belonging to the outer-ramp setting. The land influence was not intense, and the pelagic/hemipelagic accumulation prevailed in the basin.

- The studied exotics share numerous facies characteristics with other synchronous carbonates widely distributed over the northern shelf area of the Western Tethys (e.g., southern Poland, southern Germany, Carpathian Foredeep). Coeval strata known from the southern part of the Magura Basin that stretched south of the Silesian Ridge and of the Penninic-Pieninic Ocean south of the Czorsztyn Ridge yielded different microfacies reflecting significant differences between the sedimentary settings of the study area and its southern extensions.

- The exotic limestone clasts originate from the period when destruction of the southern margin of the North European Platform has commenced. These limestones were possibly deposited in the areas of both the Silesian and the Baška-Inwałd ridges, which were a southward extension of parallel ridges and grabens that divided the northern Tethys shelf as a result of synsedimentary tectonic movements. The gradual evolution of this system finally resulted in the development of the proto-Silesian Basin.

Acknowledgements JKK work was partly supported by the National Science Centre in Poland (Grant No. N N307 057740) and the Brian J. O'Neill Memorial Grant-in-Aid for Ph.D. Research 2014. MK research was supported by AGH Founds No. 16.16.140.315. JKK thank Barbara Olszewska, Marek Cieszkowski and Jan Golonka (Kraków) for helpful suggestions during her study. The authors are grateful to the Editor-inChief Axel Munnecke, and the anonymous reviewers for their constructive comments and linguistic correction that improved the manuscript.

Open Access This article is licensed under a Creative Commons Attribution 4.0 International License, which permits use, sharing, adaptation, distribution and reproduction in any medium or format, as long 
as you give appropriate credit to the original author(s) and the source, provide a link to the Creative Commons licence, and indicate if changes were made. The images or other third party material in this article are included in the article's Creative Commons licence, unless indicated otherwise in a credit line to the material. If material is not included in the article's Creative Commons licence and your intended use is not permitted by statutory regulation or exceeds the permitted use, you will need to obtain permission directly from the copyright holder. To view a copy of this licence, visit http://creativecommons.org/licenses/by/4.0/.

\section{Appendix}

List of the identified taxa.

Calcareous-walled dinoflagellate cysts

Cadosina parvula Nagy, 1966

Carpistomiosphaera borzai (Nagy, 1966)

Colomisphaera carpathica (Borza, 1964)

Colomisphaera fibrata (Nagy, 1966)

Colomisphaera lapidosa (Vogler, 1941)

Colomisphaera minutissima sensu Nowak, 1968

Colomisphaera pieniniensis (Borza, 1969)

Committosphaera czestochowiensis Řehánek, 1993

Crustocadosina semiradiata semiradiata (Wanner, 1940)

Stomiosphaera moluccana Wanner, 1940

Foraminifers

Ammobaculites irregularis (Gümbel, 1862)

Bullopora tuberculata (Sollas, 1877)

"Compactogerina stellapolaris"

Cornuspira Schultze 1854

"Cornuspira eichbergensis"

Eomarssonella paraconica Levina, 1972

Globuligerina oxfordiana (Grigelis, 1958)

Lenticulina Lamarck, 1804

Mohlerina basiliensis (Mohler, 1938)

Neotrocholina valdensis Reichel, 1955

Nubecularia Defrance, 1825

Ophthalmidium bolgradensis (Ivanova et Dain, 1971)

Ophthalmidium pseudocarinatum (Dain, 1963)

Ophthalmidium strumosum (Gümbel, 1862)

Protomarssonella jurassica (Mityanina, 1957)

Protopeneroplis striata Weynschenk, 1950

Pseudomarssonella? dumortieri (Schwager, 1866)

Reophax de Montfort, 1808

Rumanolina feifeli elevata (Paalzow, 1932)

Rumanolina feifeli feifeli (Paalzow, 1932)

Rumanolina feifeli seiboldi (Lutze, 1960)

Spirillina andreae Bielecka, 1960

Spirillina elongata Bielecka et Pożaryski, 1954

Spirillina tenuissima Gümbel, 1862

Textularia Defrance, 1824

Other microfossils

Crescentiella morronensis (Crescenti, 1969)
Globochaete alpina Lombard, 1945

Saccocoma Agassiz, 1836

Terebella lapilloides Münster, 1833

Organic-walled dinoflagellate cysts

Acanthaulax venusta (Klement, 1960)

Aldorfia Stover et Evitt 1978

Chlamydophorella Cookson et Eisenack, 1958

Chlamydophorella nyei Cookson et Eisenack, 1958

Cleistosphaeridium iaculigerum (Klement, 1960)

Cribroperidinium nuciforme (Deflandre, 1939)

Ctenidodinium Deflandre, 1938

Dingodinium tuberosum (Gitmez, 1970)

Ellipsoidictyum cinctum Klement, 1960

Endoscrinium luridum (Deflandre, 1938)

Epiplosphaera Brenner, 1988

Epiplosphaera areolata Klement, 1960

Epiplosphaera bireticulata Klement, 1960

Epiplosphaera gochtii (Fensome, 1979)

Glossodinium dimorphum Ioannides et al. 1977

Gonyaulacysta Deflandre, 1964

Gonyaulacysta jurassica (Deflandre, 1938)

Leptodinium Klement, 1960

Leptodinium subtile Klement, 1960

Lithodinia Eisenack, 1935

Mendicodinium? sp. B of Brenner, 1988

Prolixosphaeridium mixtispinosum (Klement, 1960)

Rhynchodiniopsis Deflandre, 1935

Rhynchodiniopsis cladophora (Deflandre, 1938)

Scriniodinium dictyotum Cookson et Eisenack, 1960

Sentusidinium Sarjeant et Stover, 1978

Sentusidinium rioultii (Sarjeant, 1968)

Sentusidinium sparsibarbatum Erkmen et Sarjeant, 1980

Systematophora Klement, 1960

Systematophora areolata Klement, 1960

Systematophora penicillata (Ehrenberg, 1843)

Systematophora valensii (Sarjeant, 1960)

Systematophora varispinosa Brenner, 1988

Systematophora vestita Deflandre, 1938

Tubotuberella Vozzhennikova, 1967

Tubotuberella apatela (Cookson et Eisenack, 1960)

Tubotuberella uncinata (Brideaux, 1977)

Tubotuberella ?whatleyi (Sarjeant, 1972)

Valensiella Eisenack, 1963

\section{References}

Allenbach RP (2002) The ups and downs of 'Tectonic Quiescence'recognizing differential subsidence in the epicontinental sea in the Oxfordian in the Swiss Jura Mountains. Sediment Geol 150:323-342. https://doi.org/10.1016/S0037-0738(01)00202-0

Aubrecht R, Szulc J (2006) Deciphering of the complex depositional and diagenetic history of a scarp limestone breccia (Middle 
Jurassic Krasin Breccia, Pieniny Klippen Belt, Western Carpathians). Sediment Geol 186:265-281. https://doi.org/10.1016/j. sedgeo.2005.11.020

Balintoni IC (1998) An evolutionary model for the rift of external Carpathian flysch basin. Stud Univ Babeş-Bolyai Geol 42:119-131

Barski M, Mieszkowski R (2014) Upper Jurassic large-scale debris flow deposits in interbiohermal basins of the sponge megafacies in Poland—new insights. Neu Jahrb Geol Paläont Abh 272:47-59. https://doi.org/10.1127/0077-7749/2014/0396

Bieda F, Geroch S, Koszarski L, Książkiewicz M, Żytko K (1963) Stratigraphie des Karpates externes polonaises. Biul Inst Geol 181:5-174

Birkenmajer K (1988) Exotic Andrusov Ridge: its role in plate-tectonic evolution of the West Carpathian Foldbelt. Stud Geol Pol 91:7-37

Borza K (1969) Die Mikrofazies und Mikrofossilien des Oberjuras und der Unterkreide der Klippen Zone der Westkarpaten. Vyd Slov akad vied, Bratislava

Brenner W (1988) Dinoflagellaten aus dem unteren Malm (oberer Jura) von süddeutschland; morphologie, ökologie, stratigraphie. Tübinger Mikropaläont Mitt 6:1-116

Burtan J, Chowaniec J, Golonka J (1984) Preliminary results of studies on exotic carbonate rocks in the western part of the Polish Flysch Carpathians. Biul Inst Geol 346:147-156 (in Polish with English summary)

Cieszkowski M, Golonka J, Krobicki M, Ślączka A, Oszczypko N, Waśkowska A, Wendorff M (2009) The Northern Carpathians plate tectonic evolutionary stages and origin of olistoliths and olistostromes. Geodin Acta 22(1-3):101-126. https://doi. org/10.3166/ga.22.101-126

Eliáš M (1970) Litologie a sedimentologie slezské jednotky v Moravskoslezských Beskydech (Lithology and sedimentology of the Silesian Unit in the Moravo-Silesian Beskydy Mts). Sbor geol Věd, Geol 18:7-99 (in Czech)

Eliáš M, Skupien P, Vašíček Z (2003) A proposal for the modification of the lithostratigraphical division of the lower part of the Silesian Unit in the Czech area (Outer Western Carpathians). Sbor Věd Prací Vys Šk Báň v Ostravě, Ř horn-geol, Monografie 8:7-14 (in Czech with English summary)

Flügel E (2004) Microfacies of carbonate rocks, analysis, interpretation and application. Springer, Berlin

Gedl P (2008) Organic-walled dinoflagellate cyst stratigraphy of dark Middle Jurassic marine deposits of the Pieniny Klippen Belt, West Carpathians. Stud Geol Pol 131:7-227

Gedl P, Szydło A (2001) Uwagi o paleośrodowisku asocjacji dinocystowych i otwornicowych z dolnych łupków cieszyńskich (polskie Karpaty zewnętrzne) (Comments on the paleoenvironment of dinocyst and foraminiferal associations from the Lower Cieszyn shale, Polish Outer Carpathians). In: Pieńkowski G, Grabowski J (eds) Polska Grupa Robocza Systemu Jurajskiego Jurassica, II Spotkanie, Starachowice 27-29.09.2001, p 11 (in Polish)

Gedl P, Ziaja J (2004) Preliminary results of palynological studies of Upper Jurassic flora-bearing deposits from Wólka Bałtowska, NE margin of Góry Świętokrzyskie, Poland. Tomy Jurajskie 2:49-59 (in Polish with English summary)

Golonka J (2004) Plate tectonic evolution of the southern margin of Eurasia in the Mesozoic and Cenozoic. Tectonophysics 381:235273. https://doi.org/10.1016/j.tecto.2002.06.004

Golonka J, Oszczypko N, Ślączka A (2000) Late CarboniferousNeogene geodynamic evolution and paleogeography of the circum-Carpathian region and adjacent areas. Ann Soc Geol Pol 70(10): 107-136

Golonka J, Gahagan L, Krobicki M, Marko F, Oszczypko N, Ślączka A (2006) Plate Tectonic Evolution and Paleogeography of the Circum-Carpathian Region. In: Golonka J, Picha F (eds) The
Carpathians and their foreland: Geology and hydrocarbon resources. AAPG Mem 84:11-46. https://doi.org/10.1306/98560 $6 \mathrm{M} 843066$

Golonka J, Krobicki M, Waśkowska-Oliwa A, Vašícek Z, Skupien P (2008a) Main paleogeographical elements of the West Outer Carpathians during Late Jurassic and Early Cretaceous times. Geologia 34:61-72 (in Polish with English summary)

Golonka J, Vašícek Z, Skupien P, Waśkowska-Oliwa A, Krobicki M, Cieszkowski M, Ślączka A, Słomka T (2008b) Lithostratigraphy of the Upper Jurassic and Lower Cretaceous deposits of the western part of Outer Carpathians (discussion proposition). Geologia 34:9-31 (in Polish with English summary)

Gradstein FM (2017) New and emended species of Jurassic planktonic foraminifera. Swiss J Paleontol 136(2):161-185. https:// doi.org/10.1007/s13358-017-0127-8

Hoffmann M, Kołodziej B, Skupien P (2017) Microencruster-microbial framework and synsedimentary cements in the Stramberk Limestone (Carpathians, Czech Republic): Insights into reef zonation. Ann Soc Geol Pol 87:325-347. https://doi.org/10.1441/ asgp.2017.018

Hohenegger L (1861) Die geognostischen Verhältnisse der Nord-Karpathen in Schlesien und den angrenzenden Theilen von Mähren und Galizien - Erläuterung zu der geognostischen Karte der Nordkarpathen. Justus Perthes, Gotha

Jach R, Reháková D, Uchman A (2012) Biostratigraphy and palaeoenvironment of the Kimmeridgian-Lower Tithonian pelagic deposits of the Krížna nappe, Lejowa Valley, Tatra Mts (southern Poland). Geol Quart 56(4):773-788. https://doi.org/10.7306/ gq.v56i4.7834

Keupp H, Matyszkiewicz J (1997) Zur Faziersrelevanz von SaccocomaResten (Schweberinoiden) in Oberjura-Kalken des nördlichen Tethys-Schelfs. Geol. Blätter für Nordost-Bayern und angrenzende Gebiete 47(1-4):53-70

Keupp H, Jenisch A, Herrmann R, Neuweiler F, Reitner J (1993) Microbial carbonate crusts: a key to the environmental analysis of fossil spongiolites? Facies 29:41-54

Kołodziej B (2015) Geological context and age of the Štramberk-type limestones from the Polish Outer Carpathians: an overview. Neu Jahrb Geol Paläont Abh 276(2):173-179. https://doi.org/10.1127/ njgpa/2015/0476

Kowal-Kasprzyk J (2016) Micropaleontological description of exotics of the Mesozoic calcareous rocks from the Silesian Nappe between the Soła and Dunajec rivers. Dissertation, Jagiellonian University (in Polish with English abstract)

Kowal-Kasprzyk J (2018) Calpionellid zones of the Tithonian-Berriasian exotic limestone clasts from the Outer Carpathians, Poland. Cretac Res 81:36-50. https://doi.org/10.1016/j.cretr es.2017.09.005

Krajewski M, Olszewska B (2006) New data about microfacies and stratigraphy of the Late Jurassic Aj-Petri carbonate buildup (SW Crimea Mountains, S Ukraine). Neu Jahrb Geol Paläont Mh 5:298-312. https://doi.org/10.1127/njgpm/2006/2006/298

Krajewski M, Schlagintweit F (2018) Crescentiella-microbial-cement microframeworks in the Upper Jurassic reefs of the Crimean Peninsula. Facies 64:21. https://doi.org/10.1007/s10347-018-0534-3

Krajewski M, Matyszkiewicz J, Król K, Olszewska B (2011a) Facies of the Upper Jurassic-Lower Cretaceous deposits from the southern part of the Carpathian Foredeep basement in the KrakówRzeszów area (southern Poland). Ann Soc Geol Pol 81:269-290

Krajewski M, Król K, Olszewska B, Felisiak I, Skwarczek M (2011b) Facies of the Upper Jurassic-Lower Cretaceous sediments at the basement of the Carpathian Foredeep (western Ukraine). Ann Soc Geol Pol 81:291-307

Krajewski M, Olchowy P, Felisiak I (2014) Lower Kimmeridgian layer with bored and encrusted hiatus concretions (Upper Jurassic, 
Central Poland): implications for stratigraphy and basin evolution. Ann Soc Geol Pol 84:113-129

Krajewski M, Olchowy P, Felisiak I (2016) Late Jurassic facies architecture of the Złoczew Graben: implications for evolution of the tectonic-controlled northern peri-Tethyan shelf (Upper Oxfordian-Lower Kimmeridgian, Poland). Facies 62:4. https://doi. org/10.1007/s10347-015-0455-3

Krajewski M, Olchowy P, Rudziński D (2018) Sedimentary successions in the middle-upper Oxfordian reef complex from the Kraków-Częstochowa Upland (Southern Poland). Geol Quart 62:653-668. https://doi.org/10.7306/gq.1429

Książkiewicz M (1931) Beobachtungen über das Auftreten der Gerölle der urkarpatischen Gesteine in den Wadowicer Karpaten. Rocz Pol Tow Geol 7:319-331 (in Polish with German summary)

Książkiewicz M (1956a) The Jurassic and Cretaceous of Bachowice. Rocz Pol Tow Geol 24(2-3):305-405

Książkiewicz M (1956b) Geology of the northern Carpathians. Geol Rundsch 45(2):369-411

Książkiewicz M (1960) Outline of the paleogeography in the Polish Carpathians. Prace Inst Geol 30:209-249 (in Polish with English summary)

Książkiewicz M (eds) (1962) Geological Atlas of Poland, stratgraphic and facial problems. Fasc. 13 - cretaceous and early tertiary in the Polish External Carpathians, 1:600 000. Wyd Geol, Warszawa

Książkiewicz M (1965) Les Cordilléres dans les mers crétacées et paléogenés des Carpathes du Nord. Bull Soc Géol France, Sér VII 7(3):443-455

Książkiewicz M (1977) Hypothesis of plate tectonic and origin of the Carpathinas. Rocz Pol Tow Geol 47(3):321-353 (in Polish with English summary)

Kutek J (1994) Jurassic tectonic events in south-eastern Poland. Acta Geol Pol 44:167-221

Leinfelder RR, Werner W, Nose M, Schmid DU, Krautter M, Laternser R, Takacs M, Hartmann D (1996) Paleoecology, growth parameters and dynamics of coral, sponge and microbolite reefs from the Late Jurassic. Göttinger Arb Geol Paläont Sb 2:227-248

Leszczyński S (1981) Ciężkowice Sandstones of the Silesian Unit in Polish Carpathians: a study of the coarse-clastic sedimentation in deep-water. Ann Soc Geol Pol 51(3-4):435-502 (in Polish with English summary)

Matyja BA (2009) Development of the Mid-Polish Trough versus Late Jurassic evolution in the Carpathian Foredeep area. Geol Quart 53:49-62. https://doi.org/10.7306/gq.v53i1.7504

Matyszkiewicz J (1996) The significance of Saccocoma-calciturbidites for the analysis of the Polish Epicontinental Late Jurassic Basin: an example from the Southern Cracow-Wieluń Upland (Poland). Facies 34:23-40. https://doi.org/10.1007/BF02546155

Matyszkiewicz J (1997) Microfacies, sedimentation and some aspects of diagenesis of Upper Jurassic sediments from the elevated part of the Northern peri-Tethyan Shelf: a comparative study on the Lochen area (Schwäbische Alb) and the Cracow area (Cracow Wielun Upland, Poland). Berliner Geowiss Abh E21:1-111

Matyszkiewicz J, Słomka T (1994) Organodetrital conglomerates with ooids in the Cieszyn Limestone (Tithonian-Berriasian) of the Polish Flysch Carpathians and their palaeogeographic significance. Ann Soc Geol Pol 63(4):211-248

Matyszkiewicz J, Słomka T (2004) Reef-microencrusters association Lithocodium aggregatum-Bacinella irregularis from the Cieszyn limestones (Tithonian-Berriasian) of the Outer Western Carpathians (Poland). Geol Carpath 55:449-456

Matyszkiewicz J, Olszewska B, Krobicki M, Golonka J (2004) Ewolucja późnojurajskiej platformy węglanowej na podstawie badań egzotyków z utworów paleocenu warstw jarmuckich (pieniński pas skałkowy, jednostka Grajcarka) (Evolution of the Late Jurassic carbonate platform based on studies of exotics from the Paleocene Jarmuta Beds, Pieniny Klippen Belt, Grajcarek
Unit). In: Egzotyki karpackie - znaczenie w rekonstrukcjach paleogeograficzno-geotektonicznych, Ogólnopolskie seminarium, 13 grudnia 2004, Kraków. AGH, Kraków, pp 33-35 (in Polish)

Matyszkiewicz J, Krajewski M, Kędzierski J (2006) Origin and evolution of an Upper Jurassic complex of carbonate buildups from Zegarowe Rocks (Kraków-Wieluń Upland, Poland). Facies 52:249-263. https://doi.org/10.1007/s10347-005-0038-9

Matyszkiewicz J, Kochman A, Duś A (2012) Influence of local sedimentary conditions on development of microbialites in the Oxfordian carbonate buildups from the southern part of the Kraków-Częstochowa Upland (south Poland). Sediment Geol 263-264:109-132. https://doi.org/10.1016/j.sedge o.2011.08.005

Matyszkiewicz J, Kochman A, Rzepa G, Gołębiowska B, Krajewski M, Gajdzik K, Żaba J (2015) Epigenetic silicification of the Upper Oxfordian limestones in the Sokole Hills (Kraków-Częstochowa Upland): relationship to facies development and tectonics. Acta Geol Pol 65:181-203. https://doi.org/10.1515/agp-2015-0007

Matyszkiewicz J, Krajewski M, Kochman A, Kozłowski A, Duliński M (2016) Oxfordian neptunian dykes with brachiopods from the southern part of the Kraków-Częstochowa Upland (southern Poland) and their links to hydrothermal vents. Facies 62:12. https://doi.org/10.1007/s10347-016-0464-x

Mišík M, Sýkora M, Jablonský J (1991) Strihovce conglomerates and South-Magura Exotic Ridge (West Carpathians). Karpaty Sér Geol 14:7-72 (in Czech with English summary)

Morycowa E, Moryc W (2011) Upper Jurassic-Lower Cretaceous carbonate complex in Dąbrowa Tarnowska-Szczucin area (Carpathians Foreland). Biul Państw Inst Geol 447:25-48 (in Polish with English summary)

Nieto LM, Reolid M, Molina JM, Ruiz-Ortiz PA, Jiménez-Millán J, Rey J (2012) Evolution of pelagic swells from hardground analysis (Bathonian-Oxfordian, Eastern External Subbetic, southern Spain). Facies 58:389-414. https://doi.org/10.1007/s1034 7-011-0281-1

Nowak J (1927) Esquisse de la tectonique de la Pologne Nakładem Komit Org II Zjazdu Słowiańskich Geografów i Etnografów, Kraków (in Polish with French summary)

Nowak W (1976) Jurassic. Outer (Flysch) Carpathians. In: Sokołowski S (ed), Geology of Poland, Stratigraphy. Part 2: Mesozoic, vol. I. Wyd Geol, Warszawa, pp 401-421

Olchowy P, Krajewski M, Felisiak I (2019) Late Jurassic facies succession of the Kleszczów Graben area (southern border of the Łódź Depression, peri-Tethyan shelf, central Poland). Geol Quart 63:657-681. https://doi.org/10.7306/gq.1496

Olivier N, Hantzpergue P, Gaillard C, Pittet B, Leinfelder RR, Schmid DU, Werner W (2003) Microbialite morphology, structure and growth: a model of the Upper Jurassic reefs of the Chay Peninsula (western France). Palaeogeogr Palaeoclimat Palaeoecol 193:383-404. https://doi.org/10.1016/S0031-0182(03)00236-0

Olóriz F, Reolid M, Rodríguez-Tovarm FJ (2003) A Late Jurassic carbonate ramp colonized by sponges and benthic microbial communities (External Prebetic, Southern Spain). Palaios 18:428545. https://doi.org/10.1669/0883-1351(2003)018\%3c052 8:ALJCRC\%3e2.0.CO;2

Olszewska B (2014) Results of micropaleontological investigations of the Upper Jurassic, Upper Cretaceous and Miocene sediments in the Trojanowice 2 and Cianowice 2 boreholes (south-eastern part of the Kraków-Częstochowa Upland). Biul Państw Inst Geol 459:109-132 (in Polish with English summary)

Olszewska B, Wieczorek J (2001) Jurassic sediments and microfossils of the Andrychów Klippes (outer western Carpathians). Geol Carpath 52(4):217-228

Olszewska B, Szydło A, Jugowiec-Nazarkiewicz M, Nescieruk P (2008) Integrated biostratigraphy of carbonate deposits of the 
Cieszyn Beds in the Polish Western Carpathians. Geologia 34(3/1):33-59 (in Polish with English summary)

Olszewska B, Paul Z, Ryłko W, Garecka M (2011) Biostratygrafia olistolitów wapiennych zewnętrznego pasa skałkowego Karpat i skał otaczających (Biostratigraphy of the calcareous olistholits of the Carpathian outer klippen belt and surrounding rocks). ALM studio-Paul Hupper, Kraków (in Polish)

Olszewska B, Matyszkiewicz J, Król K, Krajewski M (2012) Correlation of the Upper Jurassic-Cretaceous epicontinental sediments in southern Poland and southwestern Ukraine based on thin sections. Biul Państw Inst Geol 453:29-80

Oszczypko N (1975) Exotic rocks in the Palaeogene of the Magura nappe between the Dunajec and Poprad Rivers (Carpathians, Poland). Ann Soc Geol Pol 45(3-4):403-431 (in Polish with English summary)

Oszczypko N, Oszczypko-Clowes M, Salata D (2006) Exotic rocks of the Krynica Zone (Magura nappe) and their palaeogeographic significance. Geologia 32(1):21-45

Pícha JF, Stráník Z, Krejčí O (2006) Geology and hydrocarbon resources of the Outer Western Carpathians and their foreland, Czech Republic. In: Golonka J, Picha FJ (eds) The Carpathians and their foreland: geology and hydrocarbon resources. AAPG Mem 84:49-176. https://doi.org/10.1306/985607M843067

Pleş G, Bârtaş T, Chelaru R, Bucur II (2017) Crescentiella morronensis (Crescenti) (incertae sedis) dominated microencruster association in Lower Cretaceous (lower Aptian) limestones from Rarău Massif (Eastern Carpathians, Romania). Cretaceous Res 79:91-108. https://doi.org/10.1016/j.cretr es.2017.07.015

Poulsen NE (1991) Upper Jurassic dinocyst stratigraphy in the Danish Central Trough. In: Michelsen O, Frandsen N (eds) Jurassic stratigraphy in the southern Central Trough. Geol Surv Den, Ser B 16:7-15

Poulsen NE (1992) Jurassic dinoflagellate cyst biostratigraphy of the Danish Subbasin in relations to sequences in England and Poland; a preliminary review. Rev Palaeobot Palynol 75:33-52. https://doi.org/10.1016/0034-6667(92)90148-A

Poulsen NE (1993) Dinoflagellate cyst biostratigraphy of the Oxfordian and Kimmeridgian of Poland. Acta Geol Pol 43:251-272

Poulsen NE (1996) Dinoflagellate cysts from marine Jurassic deposits of Denmark and Poland. Am Ass Strat Palynol, Contrib Ser 31:1-227

Rajchel J, Myszkowska J (1998) Exotic clasts of organodetritic algal limestones from lithosomes of the Babica Clay, Skole Unit (Outer Flysch Carpathians, Poland). Ann Soc Geol Pol 68(2-3):225-235

Reháková D (2000) Evolution and distribution of the Late Jurassic and Early Cretaceous calcareous dinoflagellates recorded in the Western Carpathian pelagic carbonate facies. Miner Slov 32:79-88

Řehánek J, Cecca F (1993) Calcareous nannofossil cysts biostratigraphy in Upper Kimmeridgian-Lower Tithonian pelagic limestones of Marches Apennines (central Italy). Rev Micropaléont 36(2):143-163

Řehánek J, Heliasz Z (1993) Microfacies and microbiostratigraphy of the Oxfordian-Lower Kimmeridgian on the basis of cadosinids and stomiosphaerids in the Częstochowa region of Poland. Geol Carpath 44(2):81-93

Reolid M, Gaillard C, Olóriz F, Rodríguez-Tovar FJ (2005) Microbial encrustations from the Middle Oxfordian-earliest Kimmeridgian lithofacies in the Prebetic Zone (Betic Cordillera, southern Spain): characterization, distribution and controlling factors. Facies 50:529-543. https://doi.org/10.1007/s10347-004-0030-9

Riding JB, Thomas JE (1988) Dinoflagellate cyst stratigraphy of the Kimmeridge Clay (Upper Jurassic) from the Dorset coast, southern England. Palynology 12:65-88. https://doi. org/10.1080/01916122.1988.9989337
Riding JB, Thomas JE (1992) Dinoflagellate cysts of the Jurassic System. In: Powell AJ (ed) A stratigraphic index of dinoflagellate cysts. Br micropalaeont Soc Publ Series. Chapman \& Hall, London, pp 7-97

Riding R (2000) Microbial carbonates: the geological record of calcified bacterial-algal mats and biofilms. Sedimentology 47:179214. https://doi.org/10.1046/j.1365-3091.2000.00003.x

Riding R (2002) Structure and composition of organic reefs and carbonate mud mounds: concepts and categories. Earth-Sci Rev 58:163-231. https://doi.org/10.1016/S0012-8252(01)00089-7

Salamon MA, Ferré B, Szydło A, Brachaniec T, Bubík M (2019) New data on crinoid assemblages from the oldest sedimentary rocks of the Polish Outer Carpathians (Jurassic-Cretaceous). Ann Paléontol. https://doi.org/10.1016/j.annpal.2019.05.007(in press)

Schmid DU (1996) Marine Mikrobolithe und Mikroinkrustierer aus dem Oberjura. Profil 9:101-251

Schmid DU, Leinfelder RR, Nose M (2001) Growth dynamics and ecology of Upper Jurassic mounds, with comparisons to MidPalaeozoic mounds. Sediment Geol 145:343-376. https://doi. org/10.1016/S0037-0738(01)00157-9

Schlagintweit F, Gawlick HJ (2008) The occurrence and role of microencruster frameworks in Late Jurassic to Early Cretaceous platform margin deposits of the Northern Calcareous Alps (Austria). Facies 54:207-231. https://doi.org/10.1007/s10347-007-0131-3

Senowbari-Daryan B, Bucur II, Schlagintweit F, Săsăran E, Matyszkiewicz J (2008) Crescentiella, a new name for "Tubiphytes" morronensis CRESCENTI, 1969: an enigmatic Jurassic-Cretaceous microfossil. Geol Croat 61:185-214

Sikora WJ (1976) Cordilleres of the Western Carpathians in the light of the plate tectonics theory. Przegl Geol 6:336-349 (in Polish with English summary)

Skupien P, Doupovcová P (2019) Dinoflagellates and calpionellids of the Jurassic-Cretaceous boundary, Outer Western Carpathians (Czech Republic). Cretac Res 99:209-228. https://doi. org/10.1016/j.cretres.2019.02.017

Skupien P, Smaržová A (2011) Palynological and geochemical response to environmental changes in the Lower Cretaceous in the Outer Western Carpathians; a record from the Silesian unit Czech Republic. Cretac Res 32(4):538-551. https://doi. org/10.1016/j.cretres.2011.04.001

Ślączka A (ed) (1976) Atlas of Paleotransport of Detrital Sediments in the Carpathian-Balkan Mountain System. Wyd Geol, Warszawa

Ślączka A, Kruglow S, Golonka J, Oszczypko N, Popadyuk I (2006) The General Geology of the Outer Carpathians, Poland, Slovakia, and Ukraine. In: Golonka J, Picha F (eds) The Carpathians and their foreland: geology and hydrocarbon resources. AAPG Mem 84:221-258. https://doi.org/10.1306/985610M843070

Strzeboński P, Kowal-Kasprzyk J, Olszewska B (2017) Exotic clasts, debris flow deposits and their significance for reconstruction of the Istebna Formation (Late Cretaceous-Paleocene, Silesian Basin, Outer Carpathians). Geol Carpath 68(6):562-582. https ://doi.org/10.1515/geoca-2017-0037

Trammer J (1989) Middle to upper Oxfordian sponges of the Polish Jura. Acta Geol Pol 39:49-91

Unrug R (1963) Istebna Beds-a fluxoturbidity formation in the Carpathian Flysch. Ann Soc Geol Pol 33(1):49-92

Vašíček Z (1972) Contribution to the fauna of the Lower Tesin Formation (Upper Jurassic) in the Trinec district. Sbor Věd Prací Vys Šk Báň v Ostravě, ̌̌ horn-geol 17(2):97-107

Védrine S, Strasser A, Hug W (2007) Oncoid growth and distribution controlled by sea-level fluctuations and climate (Late Oxfordian, Swiss Jura Mountains). Facies 53:535-552. https://doi. org/10.1007/s10347-007-0114-4

Wdowiarz S (1976) On the relation of the Carpathians to the Carpathian Foredeep in Poland. Przegl Geol 6:350-357 (in Polish with English summary) 
Wójcik A, Marciniec P, Nescieruk P (2006) Tokarnia IG-1. Profile Głębokich Otworów Wiertniczych 108, Państ Inst Geol, Warszawa (in Polish)

Woollam R, Riding JB (1983) Dinoflagellate cyst zonation of the English Jurassic. Inst Geol Sci London 83(2):1-44 (Report)

Woźniak T, Bania G, Mościcki WJ, Ćwiklik M (2018) Electrical resistivity tomography (ERT) and sedimentological analysis applied to investigation of Upper Jurassic limestones from the Krzeszowice Graben (Kraków Upland, southern Poland). Geol Quart 62(2):287-302. https://doi.org/10.7306/gq.v62i2.25763

Woźniak T, Bania G (2019) Analysis of the tectonic and sedimentary features of the southern margin of the Krzeszowice Graben in Southern Poland based on an integrated geoelectrical and geological studies. J Appl Geophys 165:60-76. https://doi. org/10.1016/j.jappgeo.2019.04.010

Żelaźniewicz A, Aleksandrowski P, Buła Z, Karnkowski PH, Konon A, Oszczypko N, Ślączka A, Żaba J, Żytko K (2011) Regionalizacja tektoniczna Polski (Polish tectonic regionalization). Komitet Nauk Geol PAN, Wrocław (in Polish)

Żytko K, Gucik S, Ryłko W, Oszczypko N, Zając R, Garlicka I, Nemčok J, Eliáš M, Menčík E, Dvořák J, Stráník Z, Rakús M, Matějovská O (1989) Geological map of the Western Outer Carpathians and their foreland without Quaternary formations. In: Poprawa D, Nemčok J (eds) Geological Atlas of the Western Outer Carpathians and their foreland, 1: 500 000. Pol Geol Inst, Warszawa 